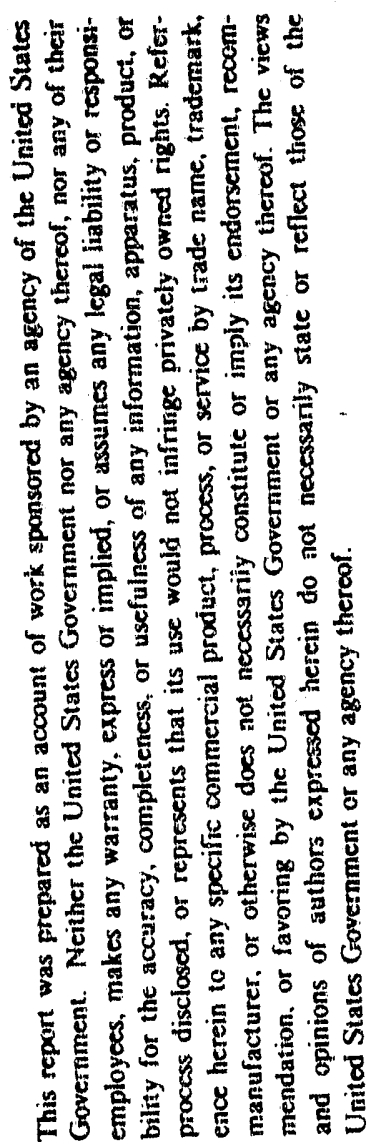

DOE/PC/89778--'T5

DE9 2018319

Technical Progress Report

10

United States Department of Energy

Pittsburgh Energy Technology Center

Attention: Mr. James D. Hickerson, Program Officer

David Hunter, Contract Specialist

Richard Rogus, Contract Officer

\title{
MOLTEN IRON OXYSULFIDE AS A SUPERIOR SULFUR SORBENT \\ DOE/DE-FG22-89PC89778
}

by

\author{
Malcolm T. Hepworth \\ Principal Investigator
}

Period Covered:

September 1, 1991 - November 30, 1991

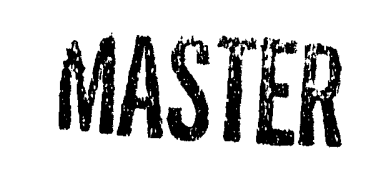




\section{ABSTRACT*}

Slagging combustors with injected lime or limestone are being considered as replacements for conventional coal burners. They have advantages in that they can be staged to reduce $\mathrm{NO}_{x}$ and $\mathrm{SO}_{x}$ emissions. Iron oxide, as an alternative to lime or limestone may be effective not only as a desulfurizing agent, but under the right conditions of oxygen potential and after combination with sulfur, the reaction products of coal gases with iron oxide can act as a flux to produce a fluid phase.

The thermodynamic conditions for optimum removal of sulfur from the first stage of a coal combustor are being determined by experiment and by use of existing data. Analysis of the phase equilibria ind cates that optimum conditions for deployment of the reducing stage of a multi-stage bi er operating with iron injection are close to the boundary of the liquid iron oxysulfi es phase with iron-saturation. Two prior investigations ${ }^{1,2}$ differ with respect to the location of this phase boundary at temperatures over $1400^{\circ} \mathrm{C}$, with reference 1 , showing the phase boundary nearer the iron-rich corner than reference 2 which gives the boundary further into the liquid region. Effort has been directed during this quarter to showing that this phase boundary is sufficiently close to the iron-rich liquid region, at higher temperatures, in order to allow for smooth operation of a multistage burner without the problem of iron deposition.

The test program utilizes thermogravimetric analysis (TGA) to establish this region of optimum burner performance by checking the calculated thermodynamic values experimentally. Preliminary kinetic data whith accompany the TGA measurements indicate that for the geometry of the measuring system, the reactions are relatively slow (compared with expected particle in-flight behaviors) because the liquid phase is being equilibrated in platinum crucibles, where permeation of the sulfur from the gas is through rnolten material several millimeters deep. (The measured time required to reach $98 \%$ saturation is approxinately 145 minutes at $1200^{\circ} \mathrm{C}$.) Actual process kinetics in which fine taconite particles $(\approx 30 \mu$ meter in diameter) are injected into an actual burner flame should exhibit more rapid reaction kinetics.

The problems of wetting of ceramic containers which was previously reported has been reduced by using platinum crucibles; however, some wall-creeping and spillage of crucible contents continues to occur on a minority of the TGA experiments.

* Underlined are key words.

1. Hilty, D. C., and Crafts: Trans. AIME, 1952, 194, p. 1307.

2. Bog, Y.S. and Rosenqvist, T.: "The Physical Chemistry of Metallic Solutions and Intermetallic Compounds," Paper 6B, NPL Symposium, No. 9, Vol II, 1959. 


\section{INTRODUCTION}

In prior quarterly reports, the combustion conditions were calculated on six Illinois Basin coals to determine what dosage of iron oxide and combustion stoichiometries are required in order to achieve a high degree of sulfur removal. Several sorbent systems were considered. These included a calcium-based system, under reducing conditions, to produce the phases $\mathrm{CaS} / \mathrm{CaO} /$ gas and under oxidizing conditions to produce $\mathrm{CaSO}_{4} / \mathrm{CaO} / \mathrm{gas}$ as well as an iron-based system. This latter system is the primary subject of this research program. Prior calculations were for the four-phase equilibrium $\mathrm{Fe} / \mathrm{FeO} /$ liquid (iron oxysulfide)/gas, for which data are available in the literature. ${ }^{3.4}$ These calculations were part of an interactive program which enabled the coal combustion conditions to be entered by an operator. The program then calculated the optimum conditions of air dosage to achieve desulfurization with lime or iron oxides. In the present quarter, effort has been directed toward studies on the desulfurization conditions of one selected lllinois Basin Coal (see Table 1).

Table 1

Analysis of Illinois Basin Coal IBC 107 (Herrin)*

\begin{tabular}{|l|c|}
\hline \multicolumn{1}{|c|}{ Constituent } & Percent by Weight \\
\hline Hydrogen & 5.0 \\
\hline Nitrogen & 1.2 \\
\hline Total Sulfur & 3.87 \\
\hline Oxygen & 10.56 (not included in ash) \\
\hline Ash & 11.5 \\
\hline \hline Total & 100.0 (dry basis) \\
\hline Moisture & 9.3 \\
\hline \hline $\begin{array}{l}\text { Gross Heating } \\
\text { Value }\end{array}$ & $28415 \mathrm{Mj} / \mathrm{Kg}$ \\
\hline
\end{tabular}

Studies in this program have been conducted on the degree of desulfurization which occurs in a single-phase liquid, which we term "iron oxysulfide liquid". This single phase region can be seen in Figure 1 as occurring in a temperature trough running from upper left (near the phase wustite) to the lower right (near the phase phyrrhotite). Another somewhat less "cluttered" view of this region is shown in Figure 2. Below this singlephase liquid region is a two-phase region with tie lines shown at 1450,1400 and $1350^{\circ} \mathrm{C}$

\footnotetext{
- Coal referred to by Richard Harvey, Illinois State Geological Survey [(217) 244m0836], Letter to M. T. Hepworth $9 / 8 / 89$.
} 
connecting an iron-rich phase (bottom left-hand side of ternary diagram) with the iron oxysulfide liquid. In other words, at temperatures somewhere between 1300 and $1350^{\circ} \mathrm{C}$, compositions in this two-phase region form two immiscible liquids. At temperatures below $1300^{\circ} \mathrm{C}$ the iron oxysulfide is in equilibrium with sulfur-saturated solid iron (of very low sulfur content). The iron oxysulfide liquid is stable at temperatures as low as $920^{\circ} \mathrm{C}$, the ternary eutectic.

Figures 1 and 2 reproduce these two ternary diagrams, with the only significant differences being at the highest temperature shown $\left(1450^{\circ} \mathrm{C}\right)$ at approximately $80 \%$ iron. This disagreement in the data should not have any significant impact on the process chemistry as discussed subsequently. The calculations which were reported in previous reports showed that desulfurization levels improve with increasing temperature in the range $1200^{\circ} \mathrm{C}$ to $1450^{\circ} \mathrm{C}$, even though sulfur partial pressures tend to rise with increasing temperature. The increased solubility (i.e., wider region of stability of the liquid phase) as temperature increases more than compensates for the higher partial pressures of sulfur. An experimental program using thermogravimetric analysis TGA is being undertaken to check these calculations. Complete results of this study are still pending analysis of the data; however, the results of two tests are included in this report under the section on "Experimental Program".

\section{RESULTS OF CALCULATIONS}

Two prior investigations of the Fe-O-S system, by Hilty and Craft ${ }^{1}$ and Bog and Rosenquist ${ }^{2}$, place the boundary of the upper two-liquid phase region closer-to (ref 1) and further-from (ref 2) the iron-rich corner of the Fe-O-S system, respectively. Even for results of the second investigator, the range of compositions for desulfurization is sufficiently broad to be able maintain a stable liquid under the conditions required for effective desulfurization of coal-gases. In the following discussion, the calculation methods, which have been documented in prior reports ${ }^{5}$, are extended to higher temperatures and also to conditions where only the gas/liquid equilibrium pertains, i. e. no solid phase present.

In the following figures, data taken from Bog and Rosenqvist ${ }^{2}$, Nagamori and Kameda ${ }^{6}$, Shima and Naldrett ${ }^{7}$ are superimposed upon ternary equilibrium isothermal sections for the iron-oxygen-sulfur equilibrium system. Both an interpolation and extrapolation were made for temperatures ranging from $1000^{\circ} \mathrm{C}$ to $1500^{\circ}$. (The published data was limited to two isothermal sets: 1200 and $1450^{\circ} \mathrm{C}$.) Thu method of extending these data is shown in Appendix $\mathrm{A}$ to this report. Data on $\mathrm{SO}_{2}$ concentration and iron dosage are calculated for the coal described in Table 1. These calculated values are being verified by experiment and will be confirmed in the next quarterly report.

- Figure 3 is an isothermal section of the ternary system, Fe-O-S in cartesian coordinates showing the partial pressure of sulfur in the liquid region in terms of the iso-activity curves for sulfur expressed as $\log _{10}\left(P_{S 2}\right)$ in atmospheres at $1200^{\circ} \mathrm{C}$. 
The solid down-curving line at the bottom of the diagram is the boundary between the single-phase liquid (iron-oxysulfide), and the two-phase region: solid iron plus liquid.

- Figure 4 is the same diagram as in Figure 3, except that the superimposed isoactivity curves are for the partial pressure of oxygen expressed as $\log _{10}\left(\mathrm{P}_{\mathrm{O} 2}\right)$ also in atmospheres.

- Figure 5 is the same diagram as shown in Figures 3 and 4; however, the gas isocompositional curves expressed in pounds of $\mathrm{SO}_{2}$ per million $\mathrm{Btu}$ are superimposed upon the plot. These gas iso-compositional curves are the values which would occur under conditions of stoichiometric combustion in the secondstage of a burner: The first stage operated under sub-stoichiometric conditions, as shown in the prior Figures (Figs. 3 and 4). The locus of iso- $\mathrm{SO}_{2}$ values is plotted on this diagram as calculated from combustion of the coal composition given in Table 1. The original computer program for these calculations is given in a prior Quarterly Report. (Third Quarter Report, March 1 - June 1, 1990). Note that the lowest levels of $\mathrm{SO}_{2}$ are found at the iron-liquid boundary closest to the lower oxygen (left-hand) boundary. For compositions further into the oxysulfide phase (i. e. moving from lower left to upper right beyond the two phase boundary), $\mathrm{SO}_{2}$ levels rise rapidly. Essentially, then, desulfurization is poor at this temperature for all compositions except those close to the two-phase boundary.

- Figure 6 gives the iron dosages in te $\mathrm{ms}$ of grams $\mathrm{Fe}_{3} \mathrm{O}_{4}$ per $100 \mathrm{~g}$ coal.

- Figures 7-10 repeat the sequence of Figure, 3-6 except that the temperature is now $1300^{\circ} \mathrm{C}$, i. e. Figure 7 should be compared with Figure 3, Figure 4 with Figure 7, eic. The first feature which is noticed is that the two phase boundary has retreated somewhat toward the abscissa, indicating that the region of stability of the single phase liquid iron oxysulfide is increased. This feature has a noticeable effect in Figure 9 where the range of low $\mathrm{SO}_{2}$ pressures is greater at $1300^{\circ} \mathrm{C}$ than the comparable plot in Figure 5 at $1200^{\circ} \mathrm{C}$. (i. e. a flatter plateau of iso- $\mathrm{SO}_{2}$ curves). For example, in Figure 9, compositions where the $\mathrm{SO}_{2}$ level is less than $0.4 \mathrm{lbs} \mathrm{SO}_{2} / \mathrm{MMB} u$ is from approximately, $24 \mathrm{wt} \% \mathrm{~S}$ and $2 \mathrm{wt} \% \mathrm{O}$ to $27 \mathrm{wt} \% \mathrm{~S}$ and $6 \mathrm{wt} \% \mathrm{O}$. The dosages of iron, however, in Figure 10 show an increase to approximately $15 \%$ at $1300^{\circ} \mathrm{C}$ as compared with $12.5 \%$ at $1200^{\circ} \mathrm{C}$ for this desulfurizing region.

- Figures $11-14$ show the equilibria at $1400^{\circ} \mathrm{C}$. For these plots there is a pronounced curvature in the two-phase boundary, dropping to the lower left, consistent with the increasing range of liquid stability in the iron-sulfur binary (left-hand axis of the diagram). Returning to the over-all phase diagram shown in Figure 2, and comparing it with Figure 11, one can see that the region within the curved line is now a two phase region of liquid immiscibility: iron-saturated liquid 
and FeOS liquid. The upper boundary of this system which is shown in Figure 11 is, of course, connected with lie-lines (not shown) to the lower-sulfur region. Figure 13 now shows a wide region of low $\mathrm{SO}_{2}$ values (flatter iso- $\mathrm{SO}_{2}$ plateau) which can be accommodated within the single phase liquid at a wide range of reducing potentials (see Figure 12 for oxygen potentials). Figure 14, however, shows that the iron dosage for these high degrees of desulfurization have increased to about 17.5 grams $\mathrm{Fe}_{3} \mathrm{O}_{4}$ per $100 \mathrm{~g}$ coal.

Figures $15-18$ repeat the same sequences of Figures at $1450^{\circ} \mathrm{C}$. Again attention is drawn toward Figures 17 and 18, where one may see that very high levels of desulfurization are obtainable, but at the cost of higher levels of iron addition. In an earlier discussion of the phase equilibria, a comment was made that the two prior investigators (ref 1 and 2) report a difference in the liquidus surface between the oxysulfide and the liquid iron-rich phase; however, an examination of Figures $15-18$ demonstrates that excellent desulfurization can be achieved irrespective of either of these reported phase limits since the operating conditions which apply are well with in the area where a single-phase liquid is present. If Figures 17 and 18 are superimposed, one can see that levels of $\mathrm{SO}_{2}$ as low as 0.1 $\mathrm{lbs} / \mathrm{MM}$ Btu can be achieved at iron dosages of approximately 17.5 grams per 100 g coal.

- Figures 19.22 show the percent sulfur removal for each temperature and condition of phase equilibria in the range of temperatures from 1200 to $1450^{\circ} \mathrm{C}$. Levels of greater than $95 \%$ sulfur removal are readily achievable.

\section{EXPERIMENTAL PROGRAM}

In the prior quarter, effort was directed toward solving a containment problem associated with surface tension effects which occur upon melting combinations of iron oxide (magnetite), pyrrhotite $(\mathrm{FeS})$ and iron to form the oxysulfide phase. When these mixtures were melted in recrystallized alumina $\left(99 \% \mathrm{Al}_{2} \mathrm{O}_{3}\right)$ vessels, the contents flowed up and out of the containers onto the ceramic furnace tube which enclosed them. This spillage resulted in fusion of the tube and container and breakage of the tube.

We found that platinum crucibles as used in a thermo-gravimetric apparatus (TGA) were able to contain the majority of the melts without surface tension creepage. Also the platinum appeared not to react with the sulfide gas mixture. Pure magnetite was carefully weighted and placed in a weighed platinum crucible and then heated in an argon atmosphere to temperatures ranging from 1200 to $1400^{\circ} \mathrm{C}$.

The first series of experiments are directed to determining the equilibria in the above temperature range for experimental conditions related to the sulfidization process. In the initial set of these equilibrium experiments, described below, the sulfidizing 
conditions were fairly extreme, more consistent with the inlet gases upon combustion of high sulfur coal rather than discharge gases after sorption.

In Figure 23, Test 101 , results are shown for a test conducted at $1200^{\circ} \mathrm{C}$. The gas mixture after reaching temperature was established at $50 \% \mathrm{CO}_{2}$ and $50 \% \mathrm{CO}$. A weight loss was recorded from the magnetite, as shown in the dashed line, from 79 to $74 \mathrm{mg}$ which is essentially the expected change of 17 percent which is expected in the conversion of magnetite (approximate formula of $\mathrm{Fe}_{3} \mathrm{O}_{4}$ ) to wustite (of approximate formula $\mathrm{FeO}$, which actually ranges from 23 to $25 \mathrm{wt} \%$ oxygen depending upon whether this phase is in equilibrium with iron or with magnetite). This transformation required approximately 20 minutes for completion, i. e., before no further weight change was recorded. At this time $\mathrm{H}_{2} \mathrm{~S}$ was introduced into the gas stream at the relatively high content of $3.23 \%$ (i.e., $2 \mathrm{ml} / \mathrm{min}_{2} \mathrm{~S}, 30 \mathrm{ml} / \mathrm{min} \mathrm{CO}_{2}$, and $30 \mathrm{ml} / \mathrm{min} \mathrm{CO}$, all at STP).

The solid line in the figure, which is now shifted and replotted from zero time, shows that there was an incubation period of approximately 35 minutes in which no weight change occurred. This observation was not expected. We has set up the experimental conditions to pre-reduce the magnetite to wustite, which we had expected to be more reactive than magnetite because the surface was not being purged of oxygen from the reduction reaction. As we shall see subsequently in the next Figure, magnetite is more reactive then wustite.

The ascending curve in Figure 23 in the sulfidizing gas represents weight gain occurring upon the exchange between oxygen (atomic weight 16 ) and sulfur (atomic weight $\approx 32$ ). After 170 minutes there is an abrupt change in slope to a horizontal line, indicating no further reaction between the solid and sulfidizing gas. This result indicates that our experimental conditions with respect to determination of the reaction kinetics is far removed from actual burner conditions in which reactions between fine solid taconite concentrate and coal gas must be accomplished in tenths of a second.

The objective of these tests was to establish the equilibrium sulfur potential for a liquid phase close to the $\mathrm{Fe} / \mathrm{FeO} / \mathrm{Liquid}$ boundary, but still in the liquid phase. The slow approach to equilibrium of the specimen with the sulfidizing gas is probably a result of the fact that very poor mixing of the liquid phase occurs in the platinum crucible so that equilibration occurs through several rate limiting steps with diffusion probably being the slowest step at these temperatures. The diffusion of sulfur into and oxygen out of the melt is into a liquid phase of a depth of approximately $2 \mathrm{~mm}$. This factor probably accounts for the slow approach to equilibrium.

After no further weight change is observed with the sulfidizing gas, the gas atmosphere was shifted to argon and the sample quenched at an initial rate of about $20 \mathrm{deg} / \mathrm{min}$. No further weight change was observed upon cooling the sample. The sample was then assayed by a cor iometric method for sulfur in aqueous solution after dissociation of the sulfide in the presence of $\mathrm{V}_{2} \mathrm{O}_{5}$. Oxygen was calculated by difference. The assay on the first sample (Test 101) was $31.2 \% \mathrm{~S}, 64.2 \% \mathrm{Fe}$, and $4.6 \% \mathrm{O}$. This result places the 
composition squarely in the middle of the Fe-O-S liquid phase at partial pressures of oxygen and sulfur or $10^{-10}$ and $10^{-2}$ atmospheres, respectively. The assays for the second sample (see below) are identical within experimental error.

In Figure 24 (Test 102) the starting condition was change to include $\mathrm{H}_{2} \mathrm{~S}$ in the gas atmosphere under the same conditions of gas flow reported above. In this test, there was initially a rapid weight loss occurring over the first 2 minutes as shown in the plot, followed by a rise indicating sulfidization. Upon comparing the two plots, i.e., without and with initial sulfur in the gas atmosphere, the latter plot shows a more gradual rise than the first and also a somewhat lower plateau.

Further experimental work, especially at lower sulfur values and higher temperatures is in progress and will be reported upon in the next period.

\section{SUMMARY AND CONCLUSIONS}

The desulfurizing power and process conditions for stability and application of ironoxysulfide liquid have been established by calculation and preliminary experiment. Thermodynamic performance of the oxysulfide is improved at higher temperatures (i.e., $1400^{\circ} \mathrm{C}$ ) over lower temperatures $\left(1200^{\circ} \mathrm{C}\right)$. To date confirming tests by TGA have been at high sulfur levels in the gas phase; however, further tests at lower sulfur levels are required. Initial kinetic studies indicate that liquid specimens held in a platinum crucible give slow reaction rates. Tests on fine particles added to a coal gasifier atmosphere are required to reproduce the rapid kinetics observed in prior studies.

\section{PLANS FOR NEXT QUARTER}

In this coming quarter, TGA analysis will be conducted to check prior calculations on the equilibrium conditions for desulfurization of synthetic coal gases. The method outlined above in the section on Experimental Program will be employed to determine the degree of desulfurization which is possible. Kinetics for this system do not simulate actual combustion conditions. Tests under these circumstances require injection of taconite particles into a burner as is planned in a separate program: (DOE/DE-FG22890C89779).

\section{ACKNOWLEDGEMENT}

The assistance of $\mathrm{Mr}$. Shaolin Zhong in conducting this investigation and preparing this report is appreciated. 


\section{REFERENCES}

1. Hilty, D. C., and Crafts: Trans. AIME, 1952, 194, p. 1307.

2. Bog. Y. S. and Rosenqvist, T.: "The Physical Chemistry of Metallic Solutions and Intermetallic Compounds," Paper 6B, NPL Symposium, No. 9, Vol II, 1959.

3. Turkdogan, E.T. and Kor, G.J.W., "Sulfides and Oxides in the Fe-Mn Alloys: Part I, Phase Relations in the Fe-Mn-S-O System," Metallurgical Transactions, Vol. 2, June 1971, pps 1561-1578.

4. Turkdogan, E.T., Physico-Chemical Properties of Molten Slags and Glasses, The Metals Society, London (1983), pps. 143-151.

5. Third Quarter Report. March 1 - June 1, 1990.

6. Nagamori, M., and Kameda, M.: Japan Inst. Met. 1965, ㅁ, p. 21.

7. Shima, H. and Naldrett, A. J.: Econ. Geology, 1975, 70. p. 960. 


\section{FIGURES}




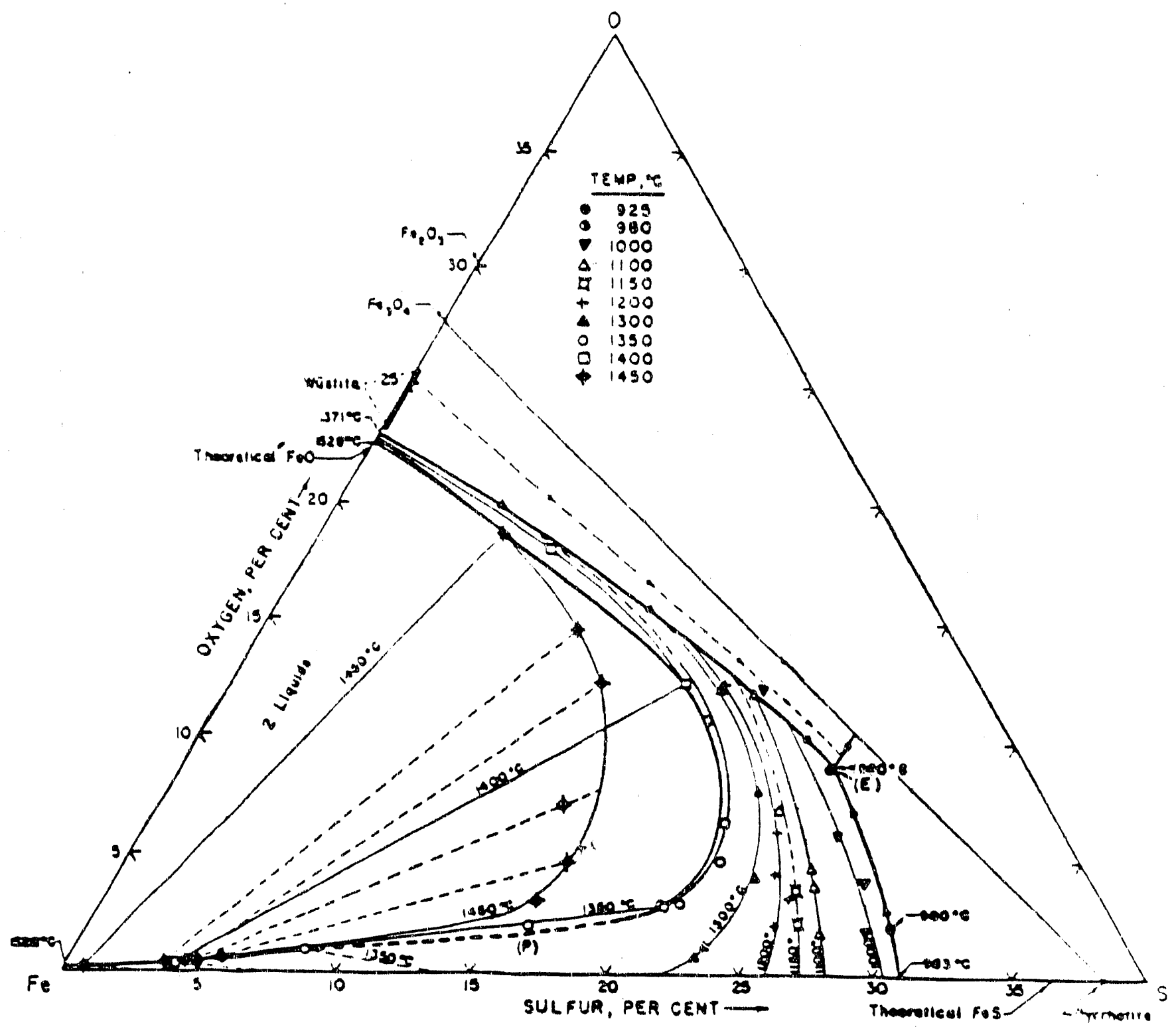

Figure 1

Fe-O-S Diagram after Hilty and Crafts ${ }^{1}$ 


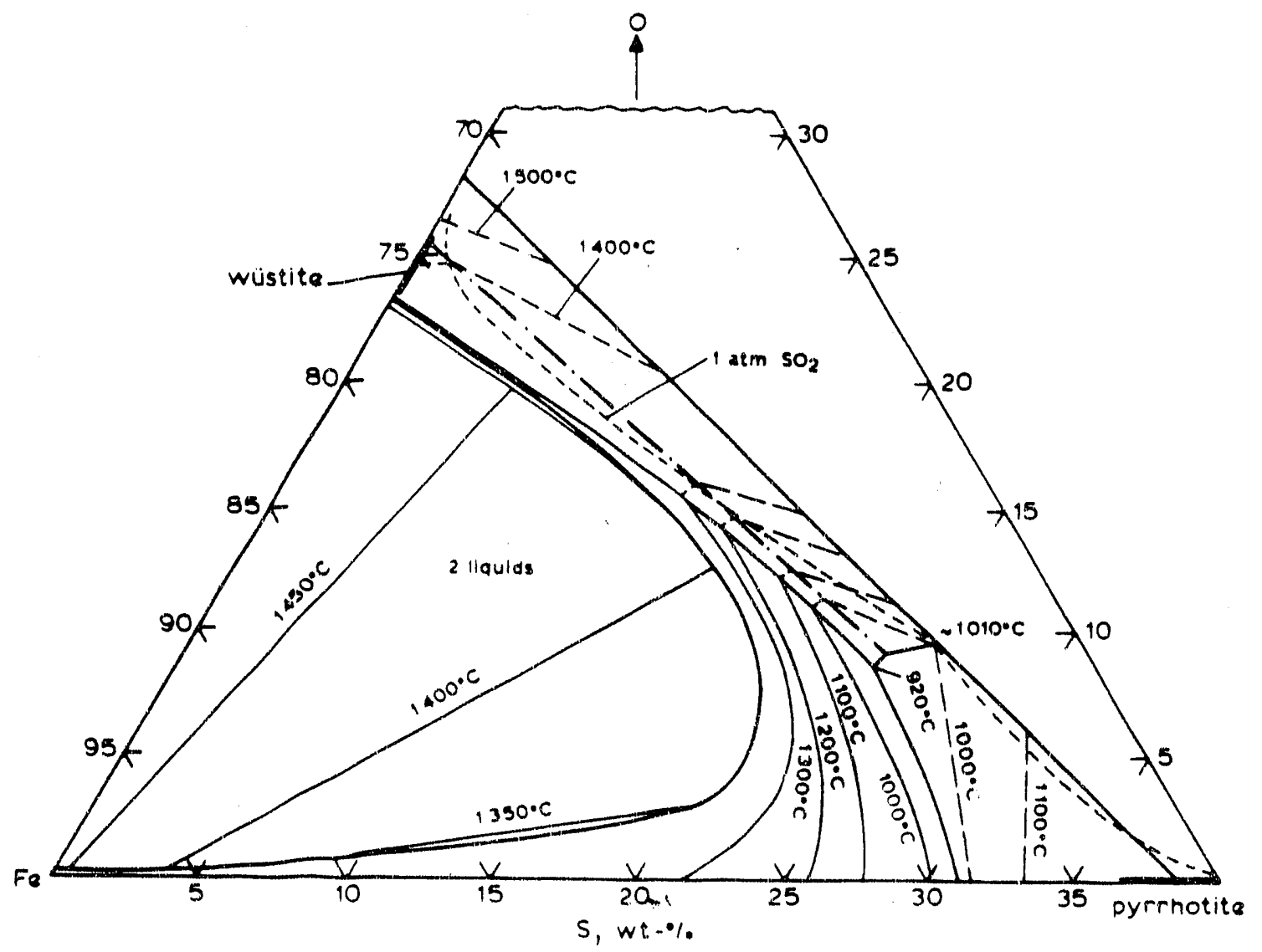

Figure 2

Fe-O-S Diagram after Bog and Rosenquist ${ }^{2}$ 


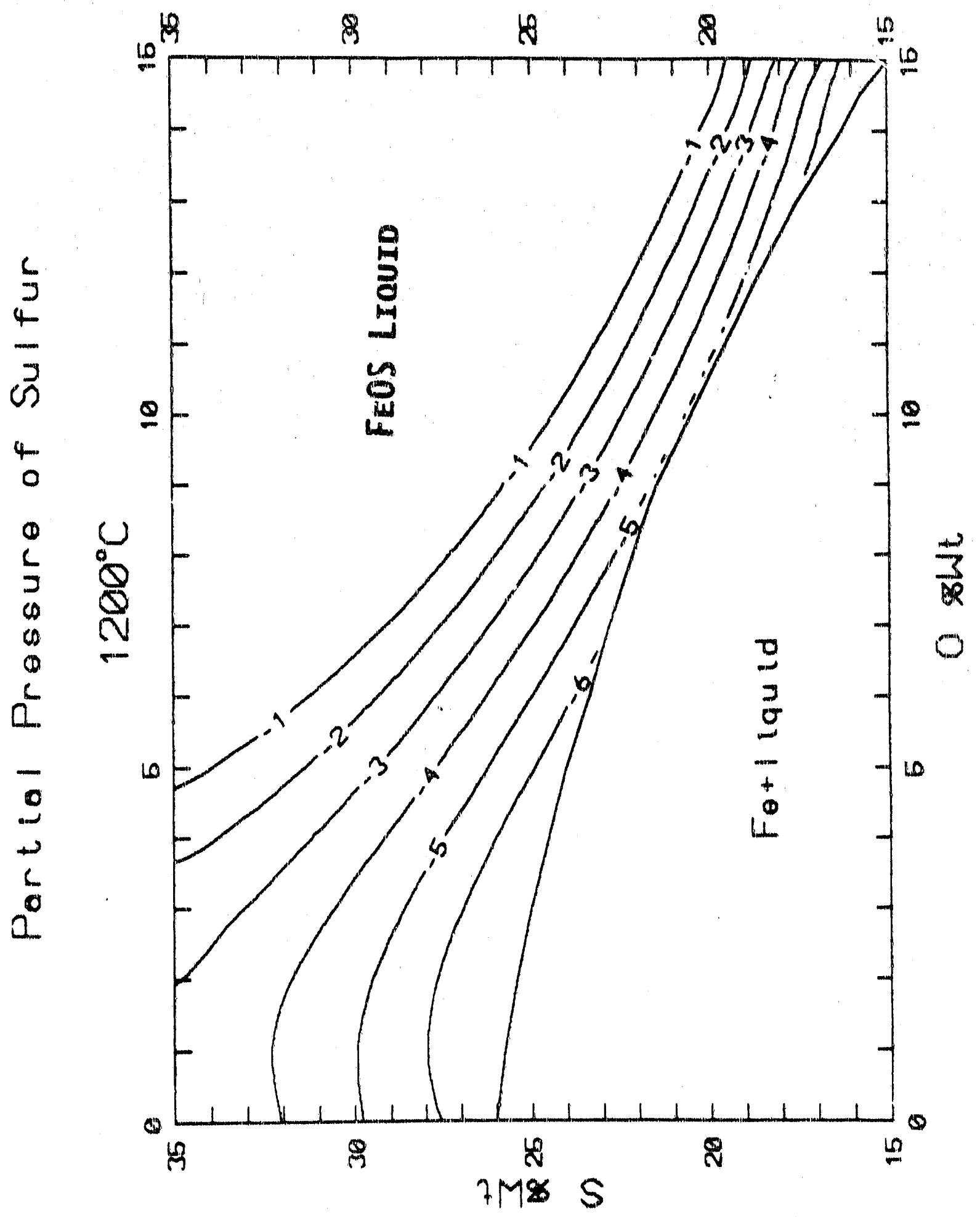

Figure 3

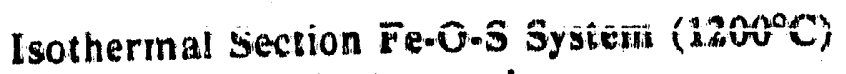

$P_{\mathrm{S} 2}$ In Atmospheres 


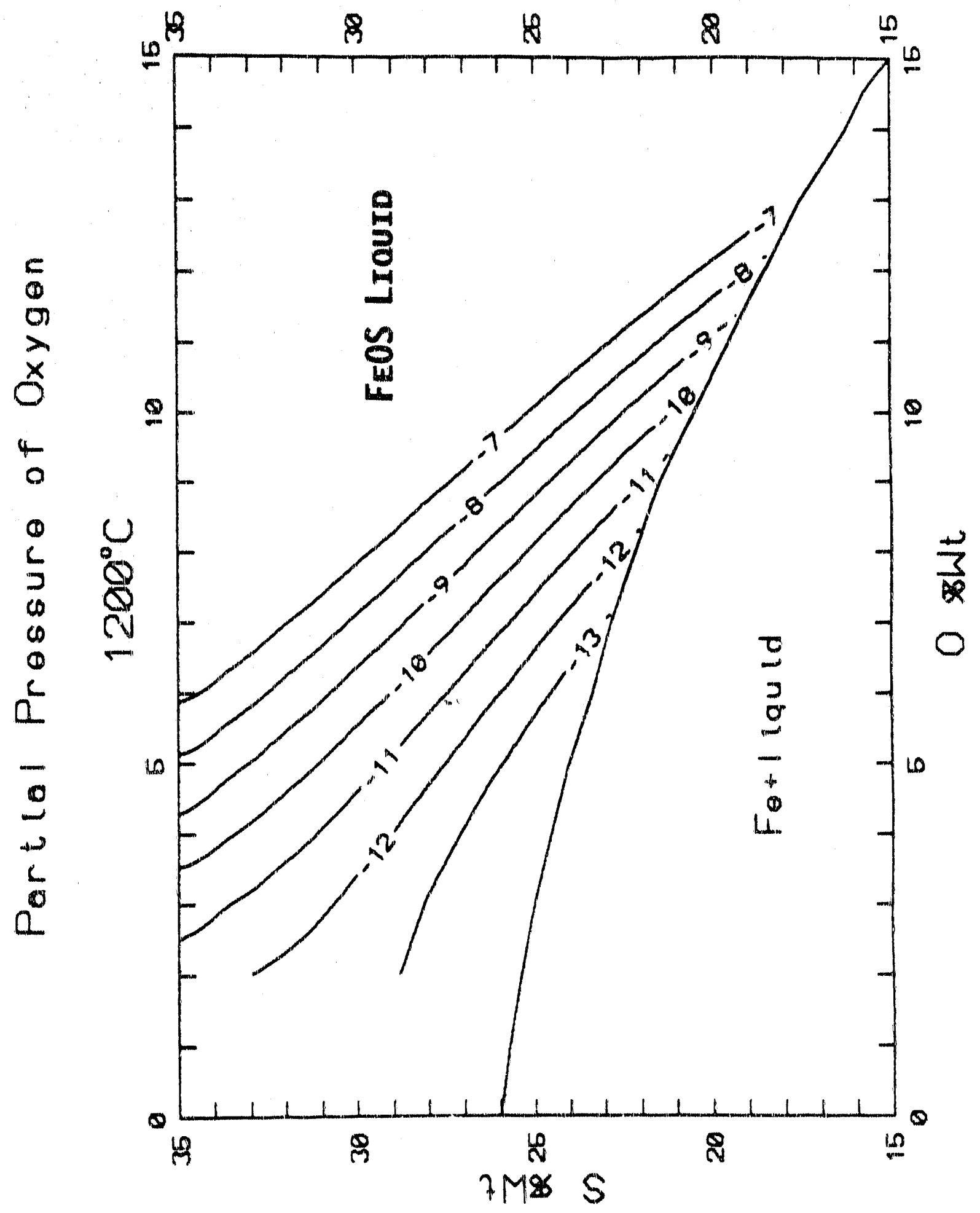

Figure 4

Isothermal Section Fe-O-S System $\left(1200^{\circ} \mathrm{C}\right)$

$\mathrm{P}_{\mathrm{O} 2}$ in Atmospheres 


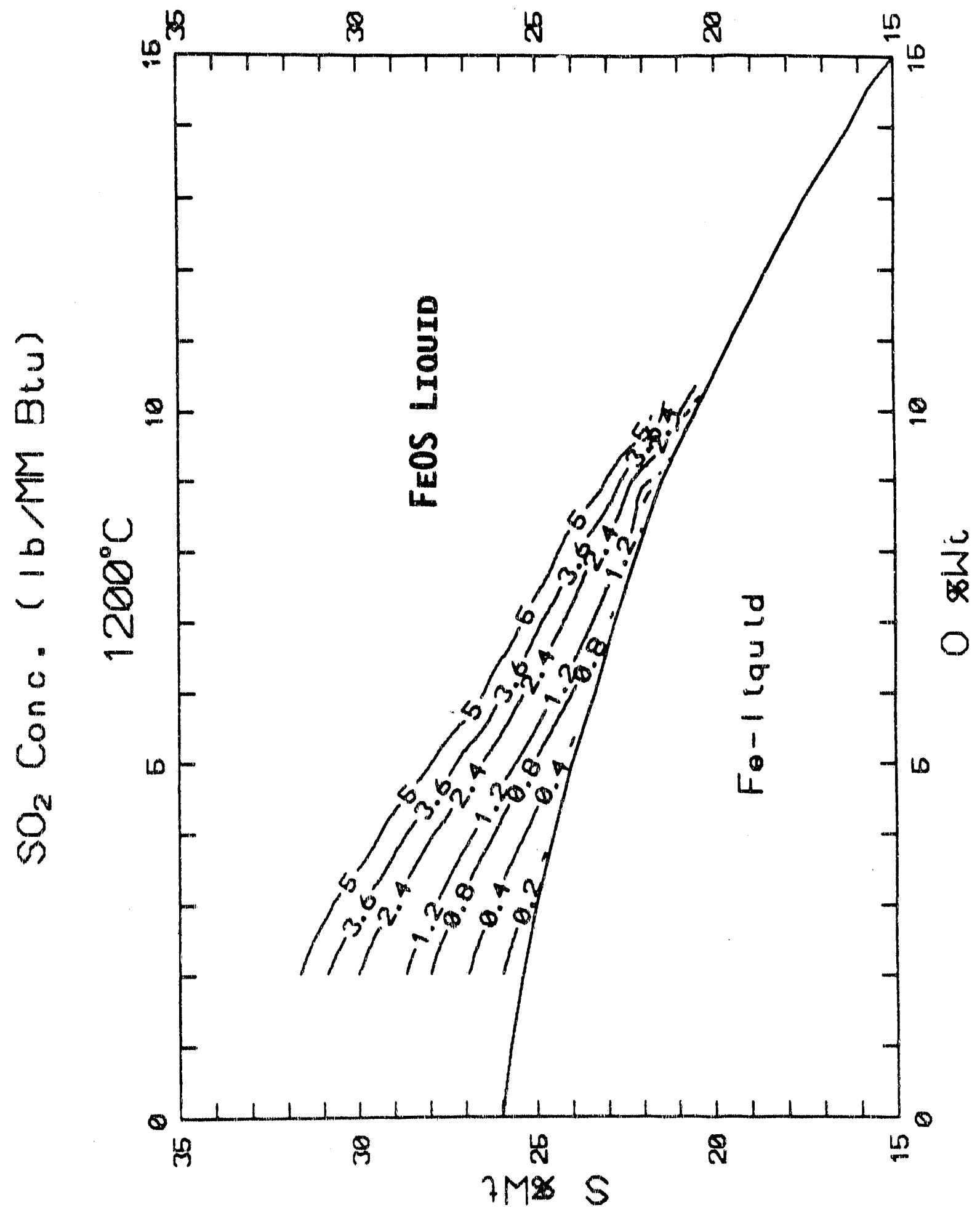

Figure 5

Isothermal Section $\mathrm{Fe}-\mathrm{O}-\mathrm{S}$ System $\left(1200^{\circ} \mathrm{C}\right)$ Iso-SO Content lbs/MMBtu Curves Superimposed Calculated for Coal IBC $\cdot 107$ Herrin 


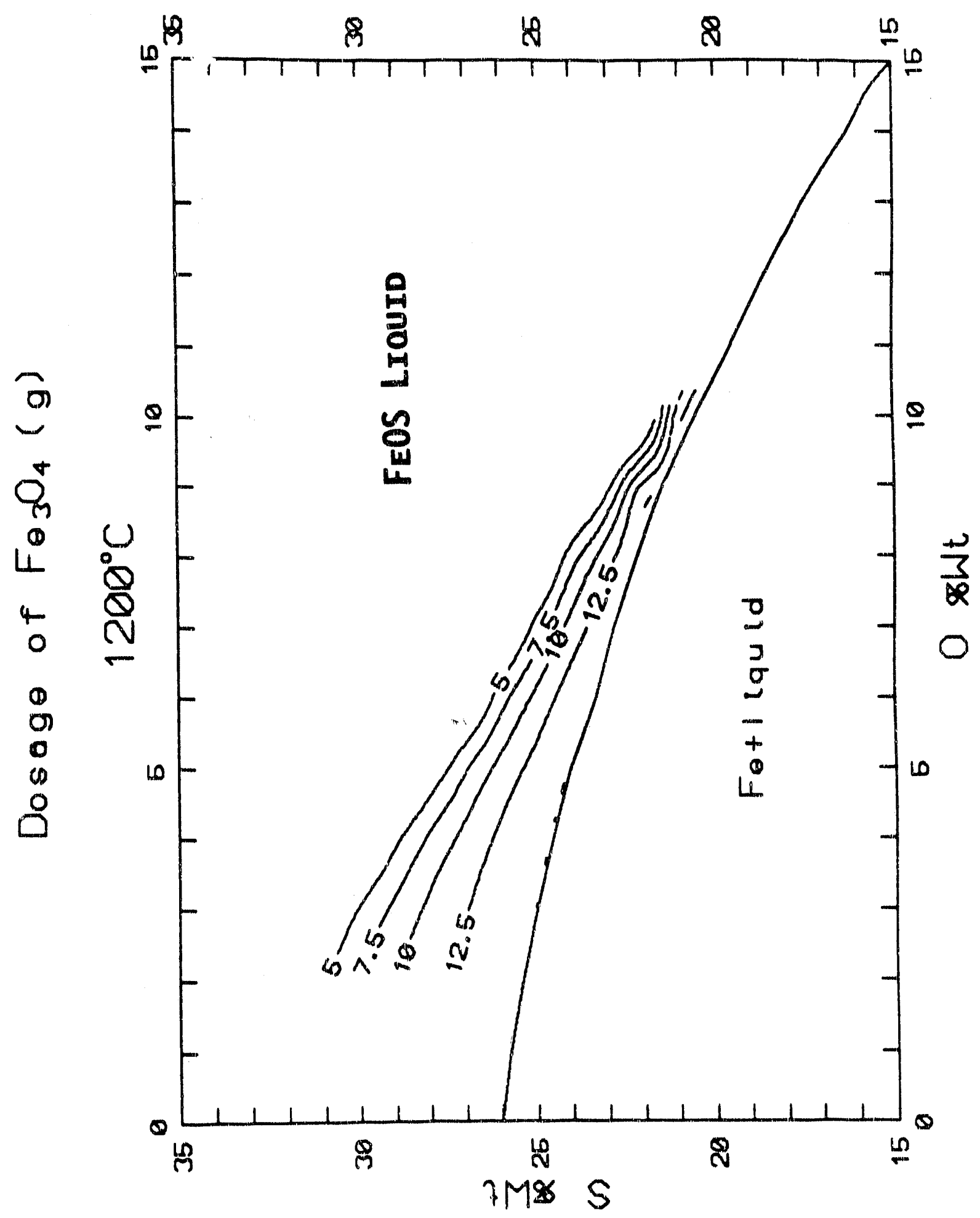

Figure 6

Isothernal Section Fe-O-S System $\left(1200^{\circ} \mathrm{C}\right)$

Dosage of $\mathrm{Fe}_{3} \mathrm{O}_{4}$ to Produce conditions of Fig 5 


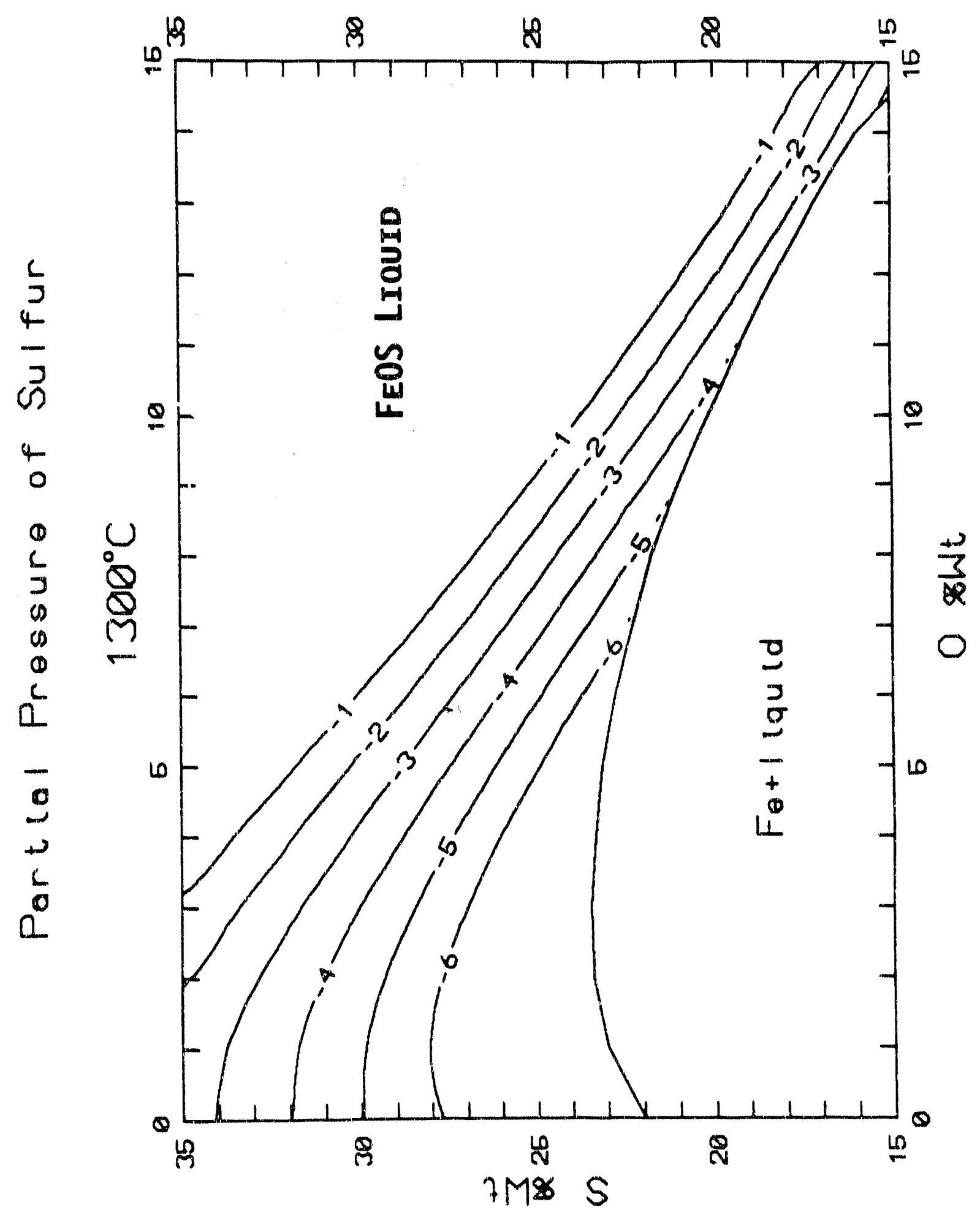

Figure 7

Isothermal Section Fe-O.S System $\left(1300^{\circ} \mathrm{C}\right)$

$\mathbf{P}_{\mathrm{S} 2}$ in Atmospheres 


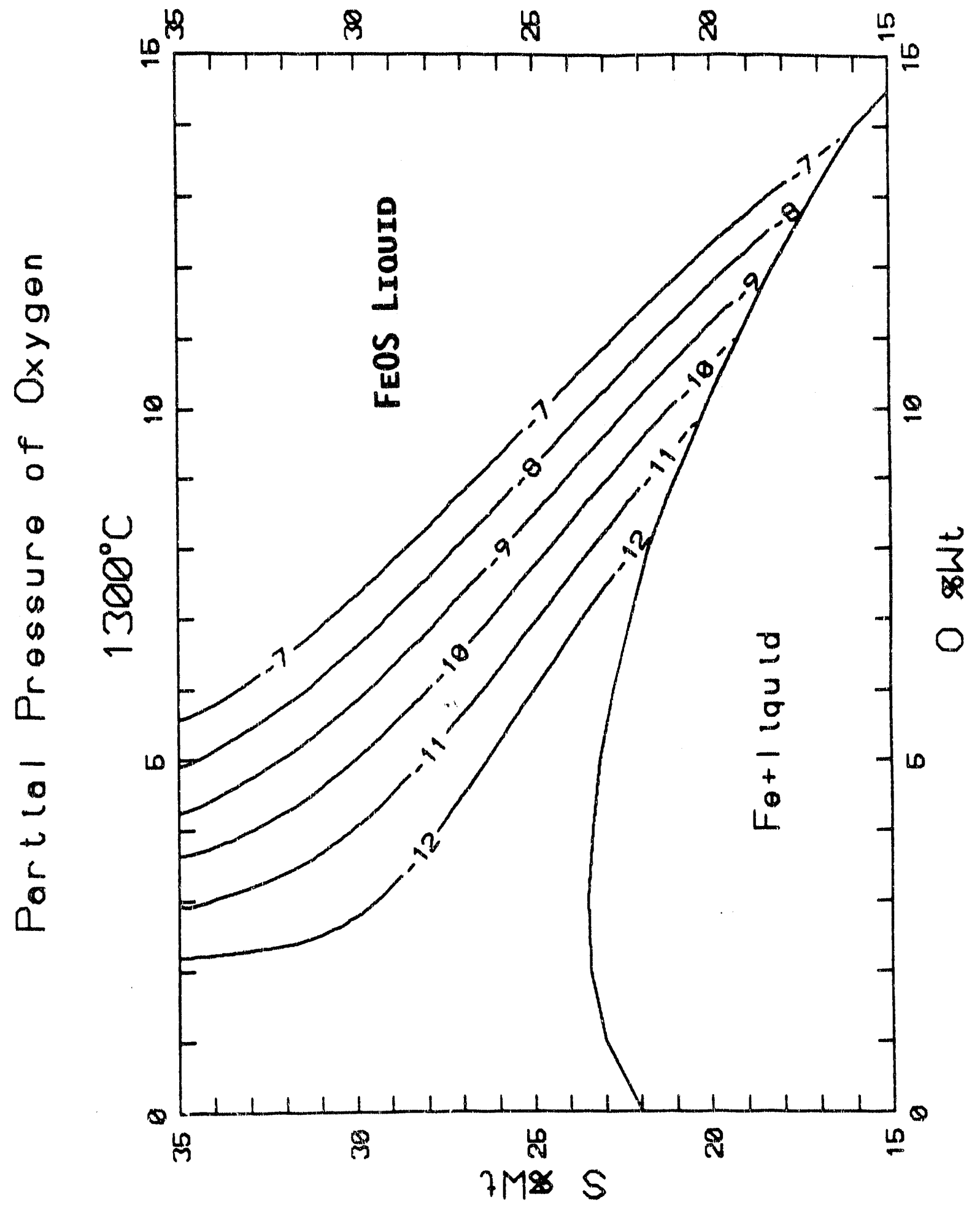

Figure 8

Isothermal Section Fe-O-S System $\left(1300^{\circ} \mathrm{C}\right)$

$\mathrm{P}_{\mathrm{O} 2}$ in Atmospheres 


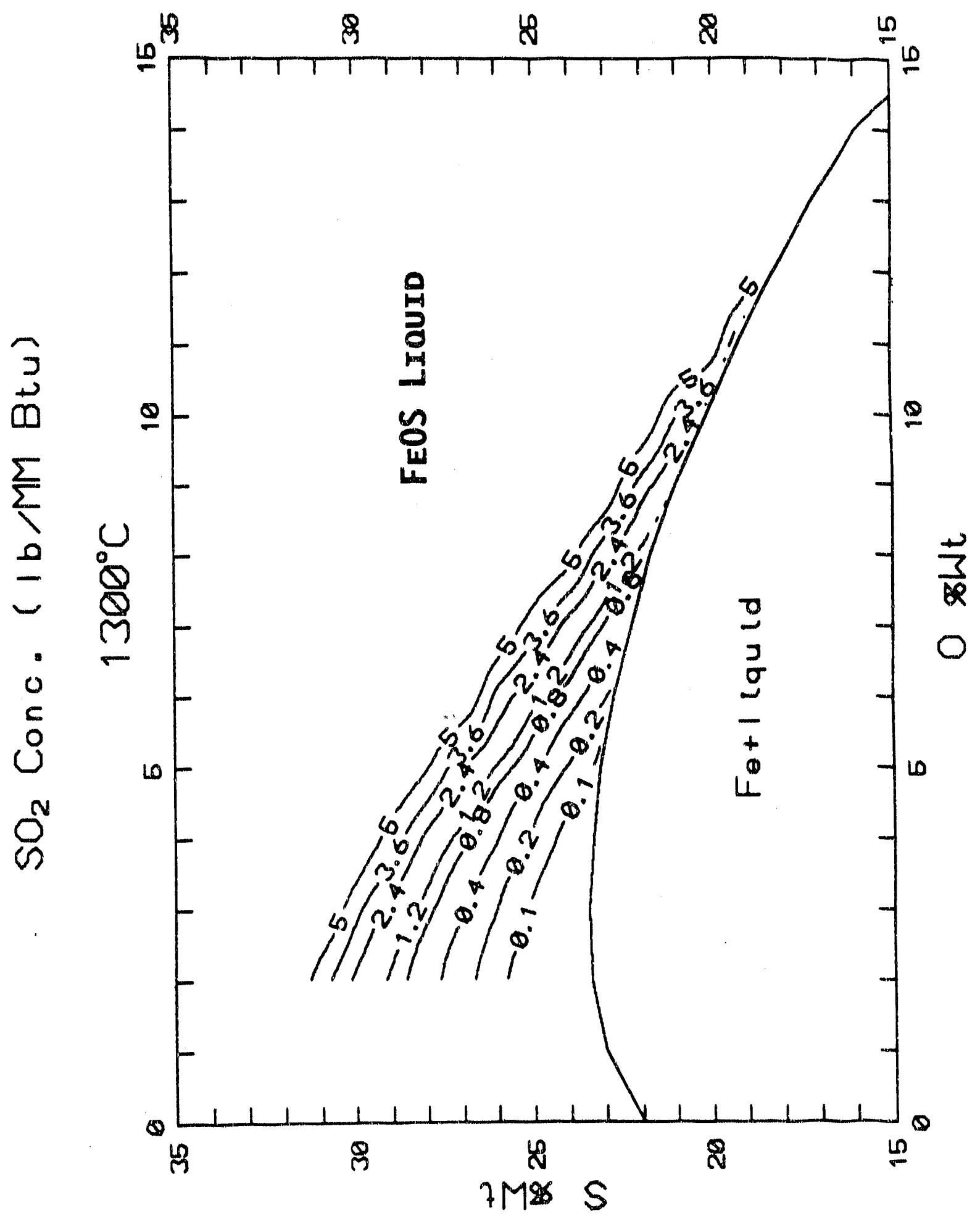

Figure 9

Isotherrnal Section Fe-O-S System $\left(1300^{\circ} \mathrm{C}\right)$ Iso-SO $\mathrm{S}_{2}$ Content Ibs/MMBtu Curves Superimposed Calculated for Coal IBC -107 Herrim 


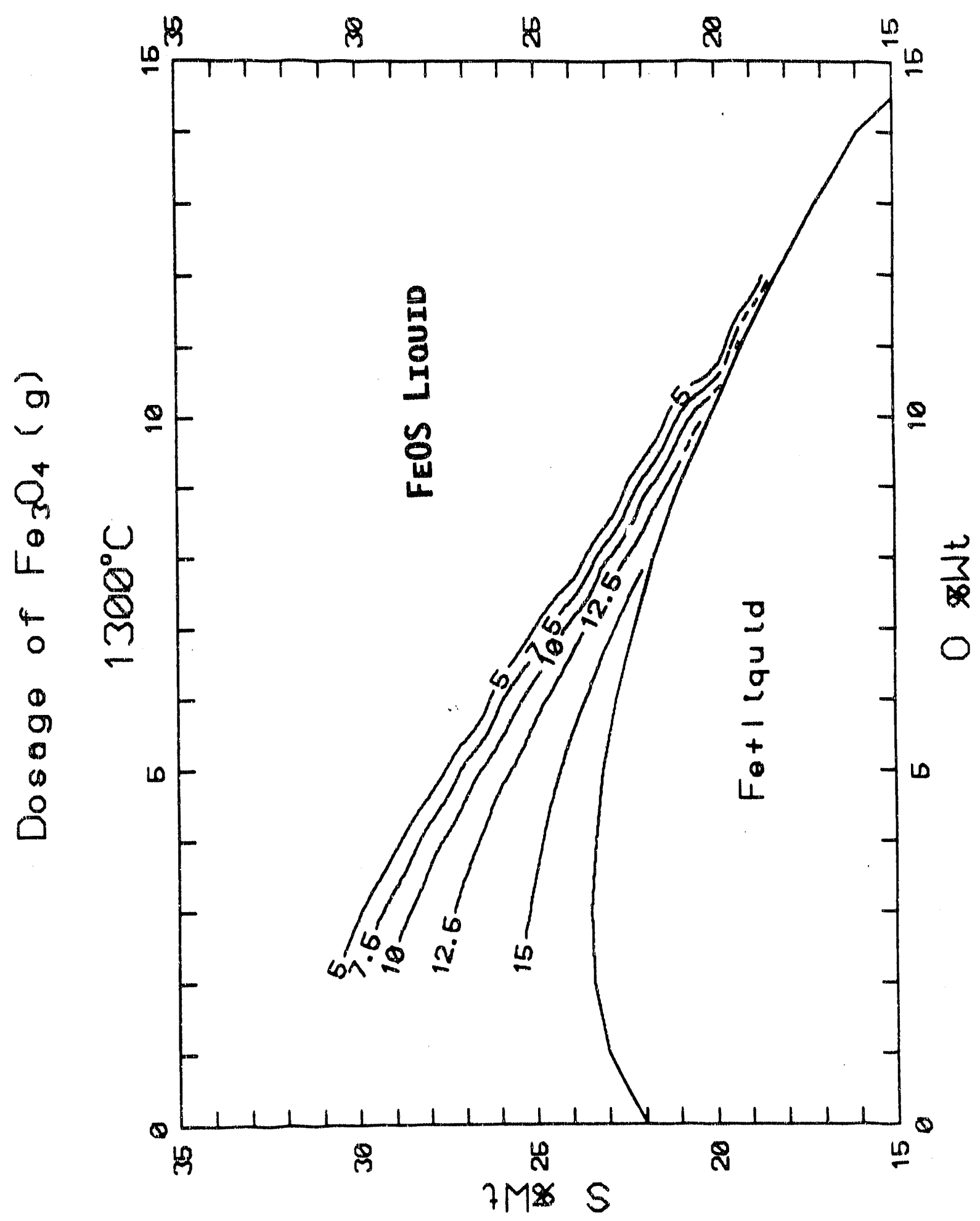

Figure 10

Isothermal Section $\mathrm{Fe}-\mathrm{O}-\mathrm{S}$ System $\left(1300^{\circ} \mathrm{C}\right)$

Dosage of $\mathrm{Fe}_{3} \mathrm{O}_{4}$ to Produce conditions of Fig 9 


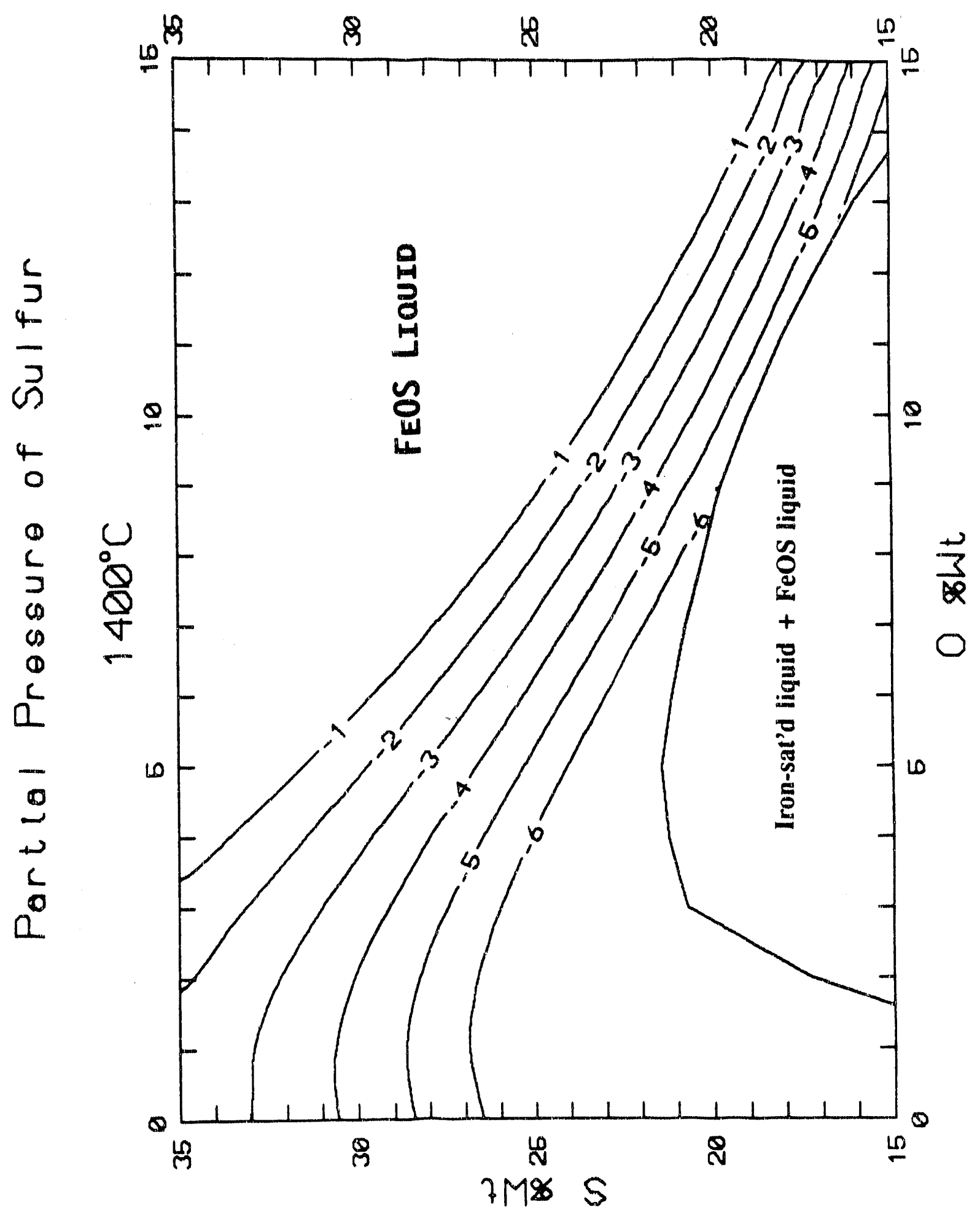

Figure 11

Isothermal Section $\mathrm{Fe}-\mathrm{O}$-S System $\left(1400^{\circ} \mathrm{C}\right)$

$\mathbf{P}_{\mathrm{S} 2}$ in Atmospheres 


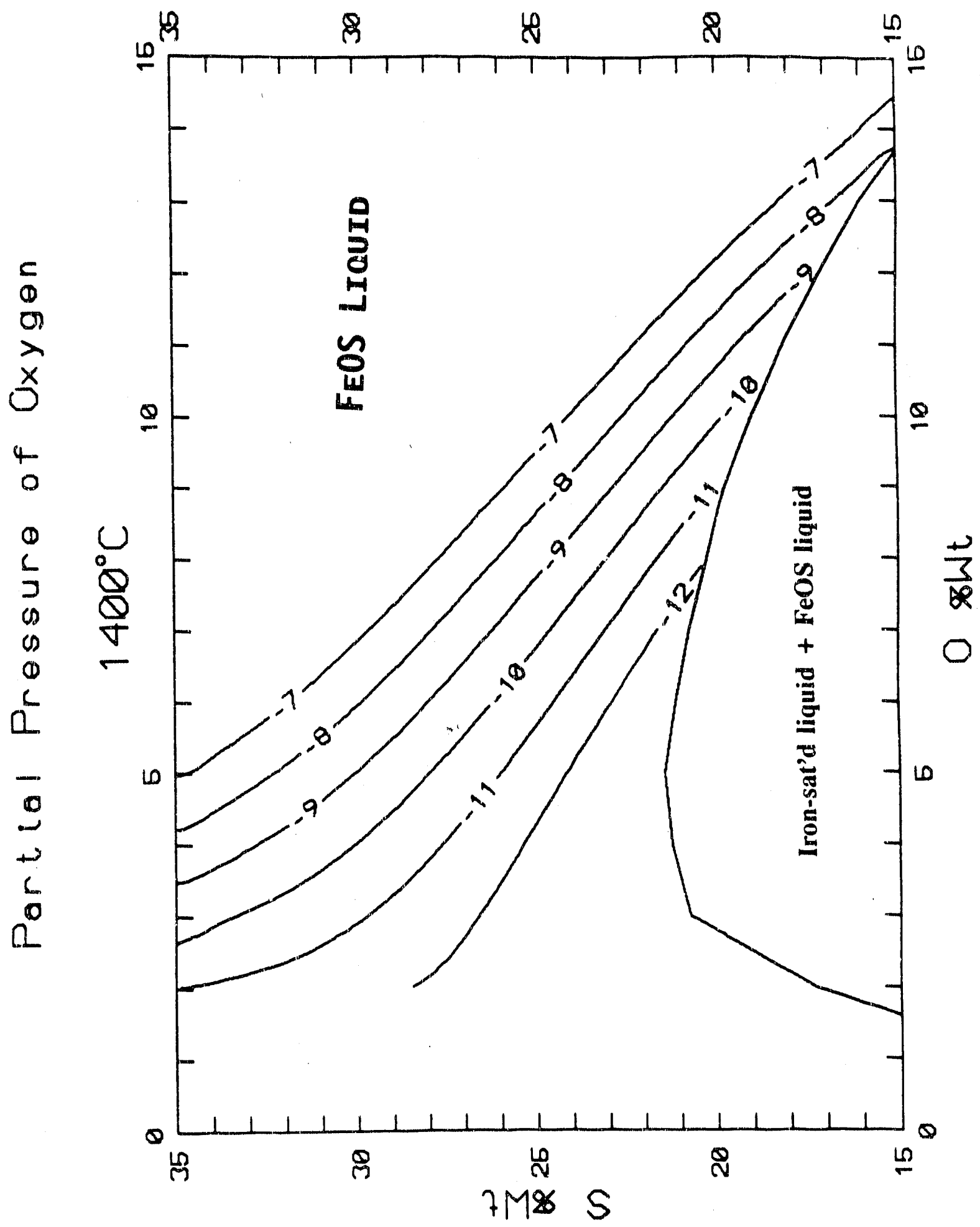

Figure 12

Isothermal Section Fe-O-S System $\left(1400^{\circ} \mathrm{C}\right)$

$\mathbf{P}_{\mathrm{O} 2}$ in Atmospheres 


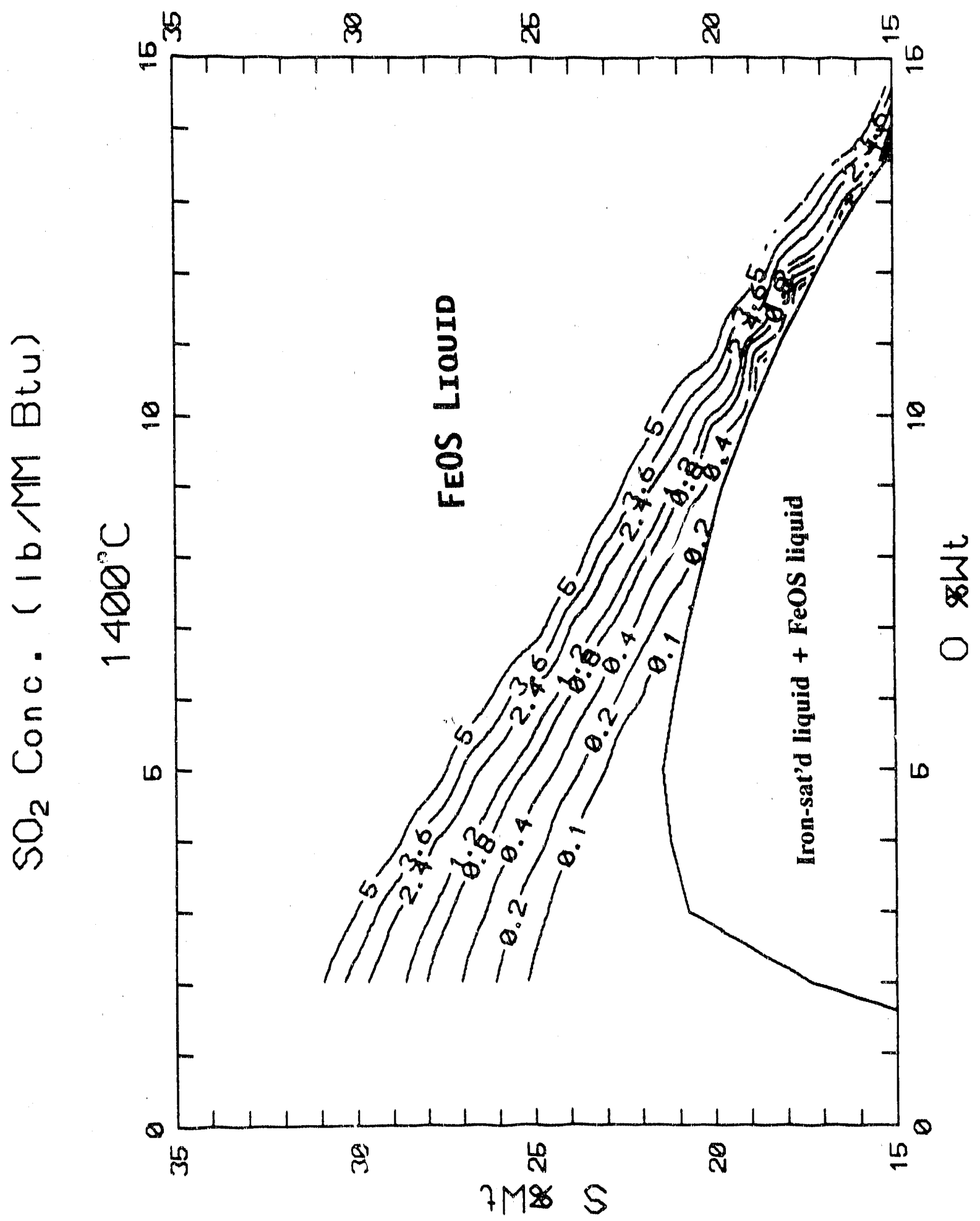

Figure 13

Isothermal Section Fe-O-S System $\left(1400^{\circ} \mathrm{C}\right)$ Iso- $\mathrm{SO}_{2}$ Content lbs/MMBtu Curves Superimposed Calculated for Coal IBC -107 Herrin 


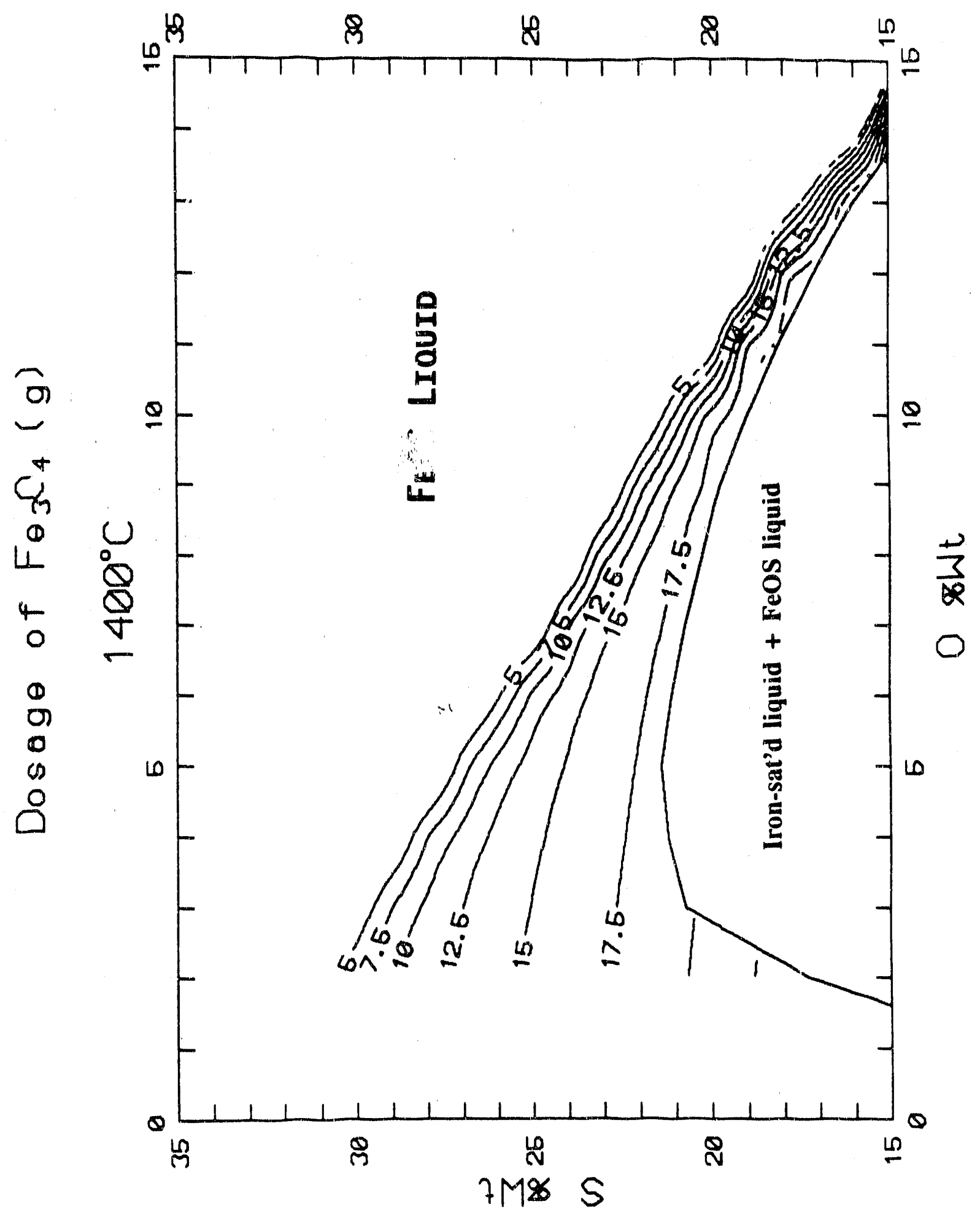

Figure 14

Isothermal Section Fe-O-S System $\left(1400^{\circ} \mathrm{C}\right)$

Dosage of $\mathrm{Fe}_{3} \mathrm{O}_{4}$ to Produce conditions of Fig 13 


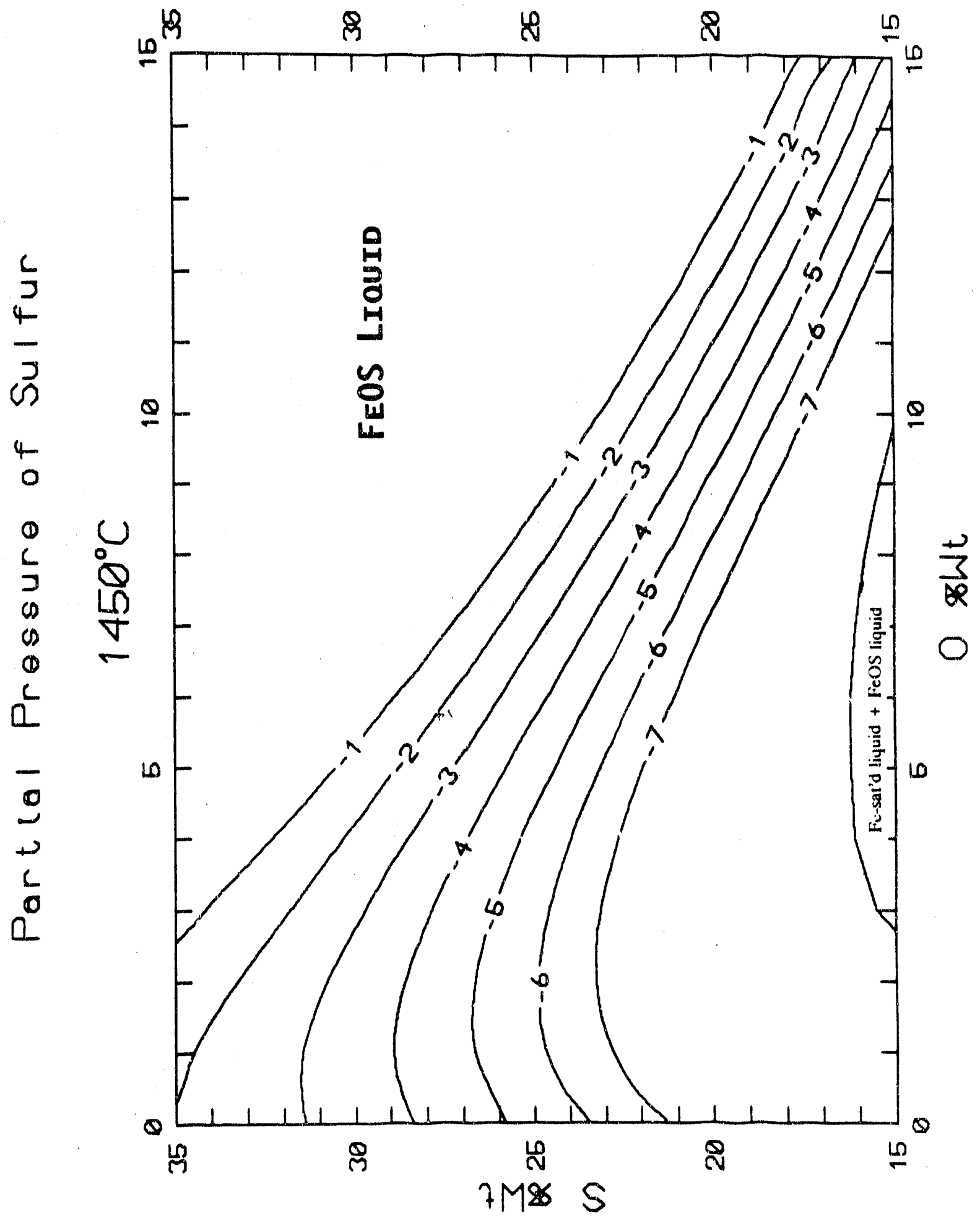

Figure 15

Isothermal Section $\mathrm{Fe}-\mathrm{O}-\mathrm{S}$ System $\left(1450^{\circ} \mathrm{C}\right)$

$$
\mathbf{P}_{\mathrm{S} 2} \text { in Atmospheres }
$$




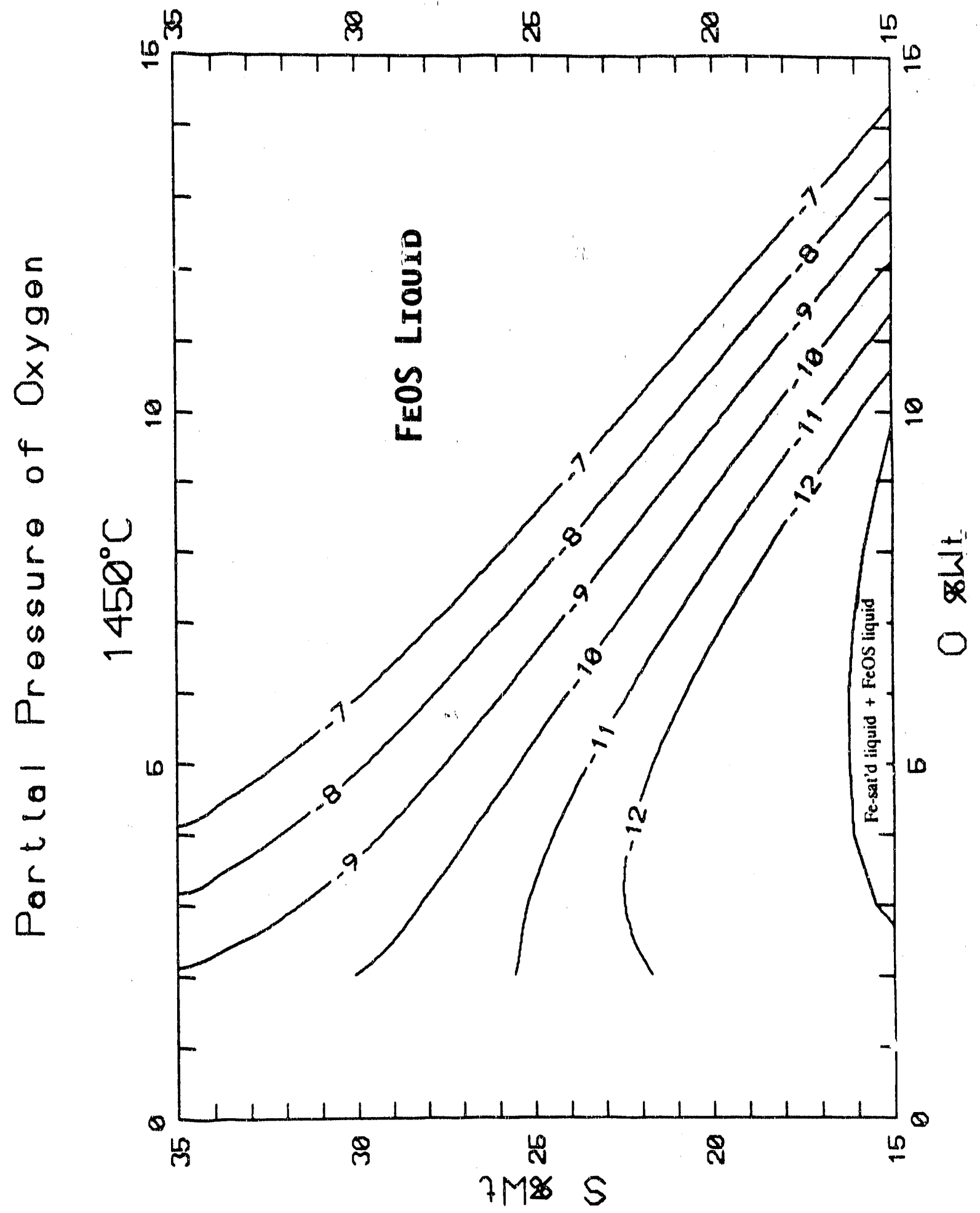

Figure 16

Isothermal Section Fe-O-S System $\left(1450^{\circ} \mathrm{C}\right)$

$\mathbf{P}_{\mathrm{O} 2}$ in Atmospheres 


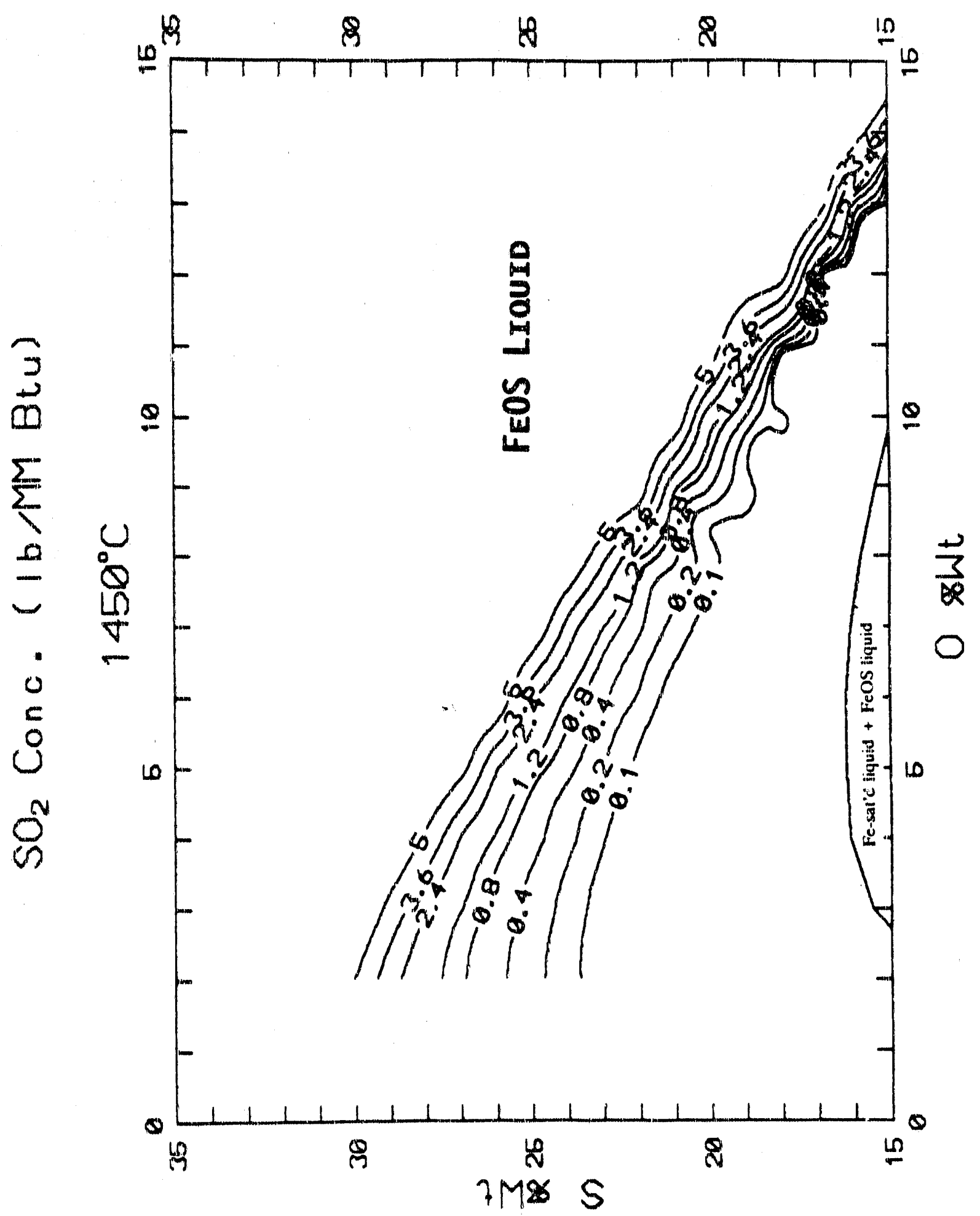

Figure 17

Isothermal Section Fe-O-S System $\left(1450^{\circ} \mathrm{C}\right)$

Iso- $\mathrm{SO}_{2}$ Content iós/Mimïitu Curves Superimpüséd

Calculated for Caal IBC - 107 Herrin 


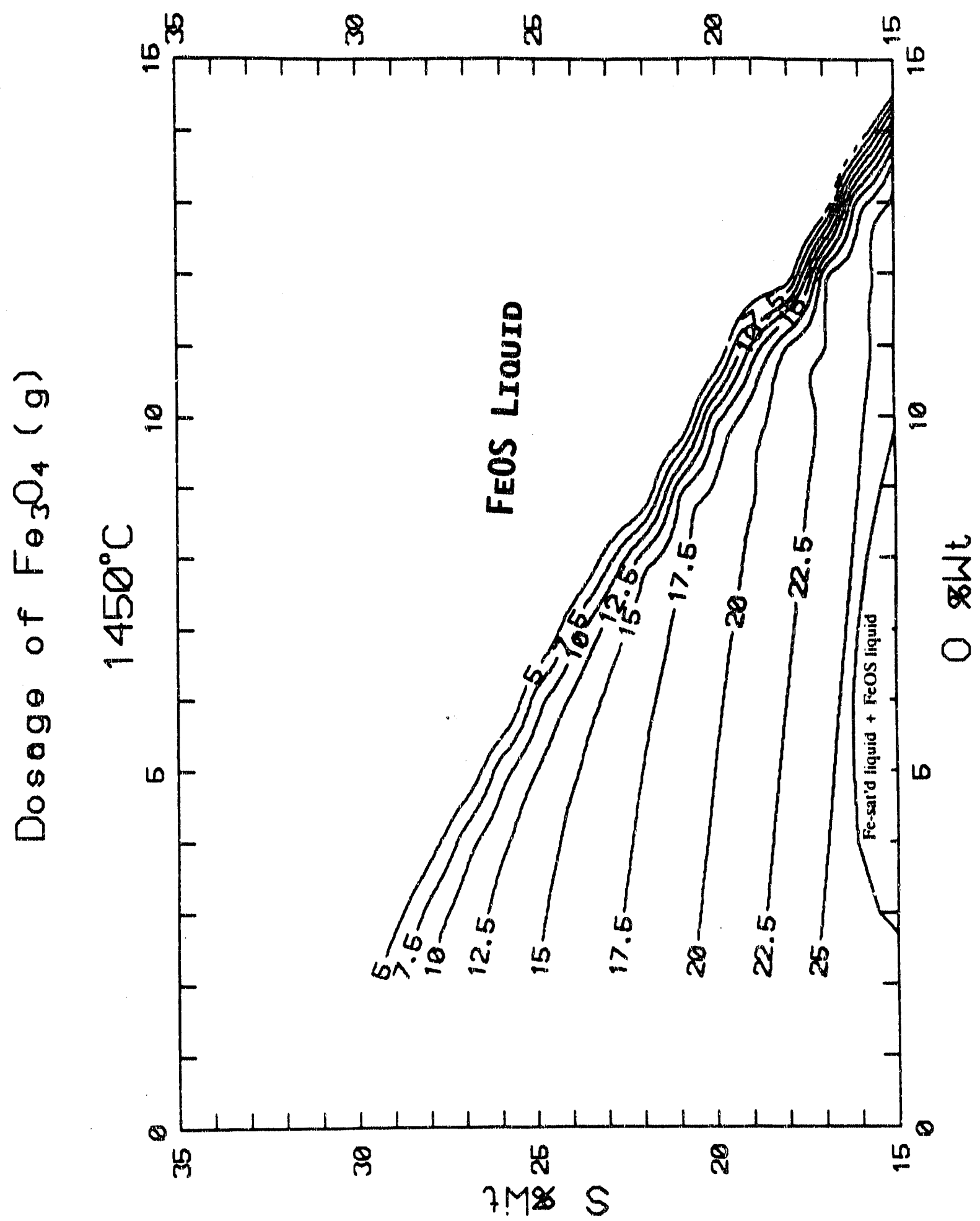

Figure 18

Isothermal Section $\mathrm{Fe}-\mathrm{O}-\mathrm{S}$ System $\left(1450^{\circ} \mathrm{C}\right)$

Dosage of $\mathrm{Fe}_{2} \mathrm{O}_{4}$ to Produce conditions of Fig 17 


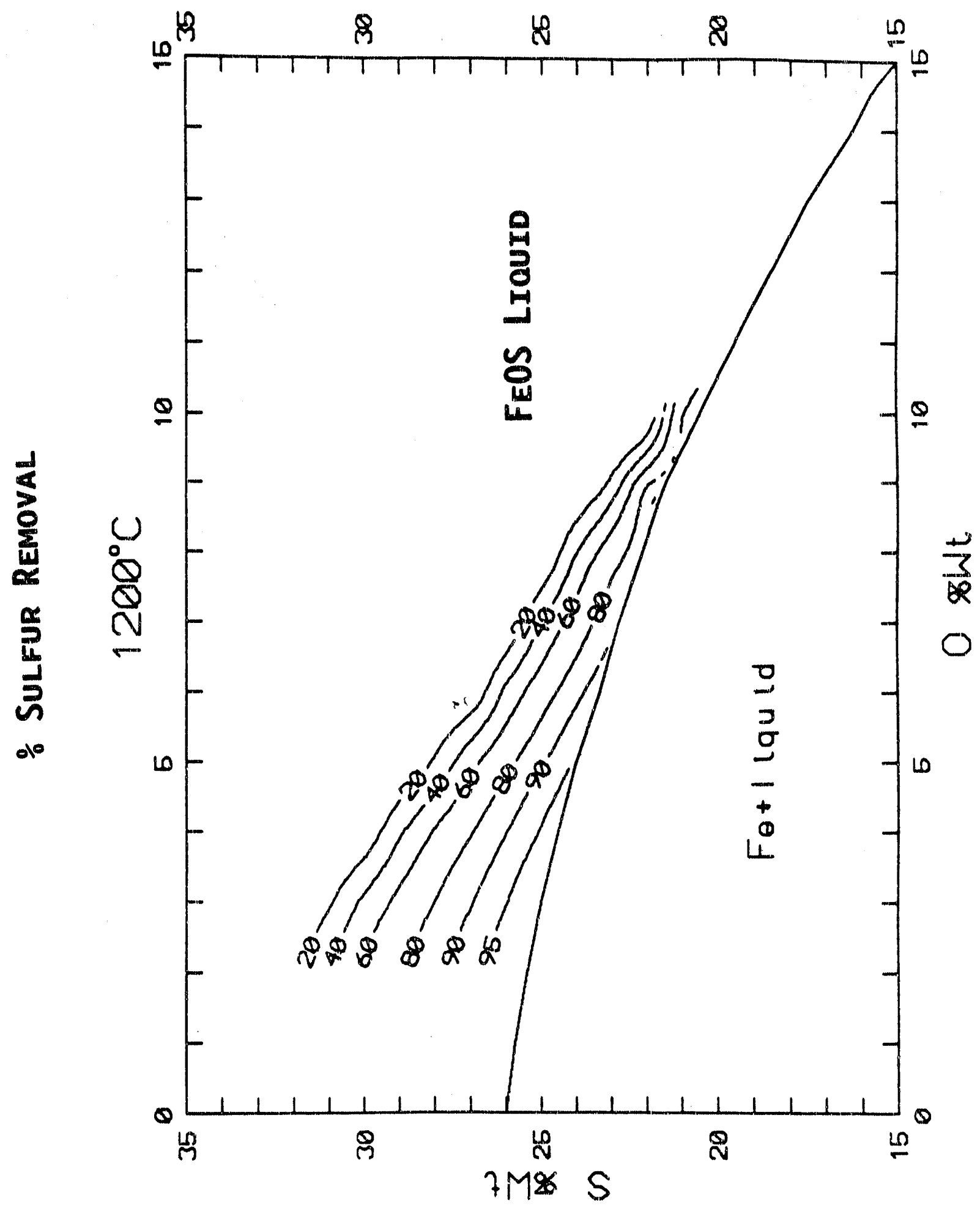

Figure 19

Isothermal Section Fe-O-S System $\left(1200^{\circ} \mathrm{C}\right)$

of Sutfur Removal at Equiltibritum 


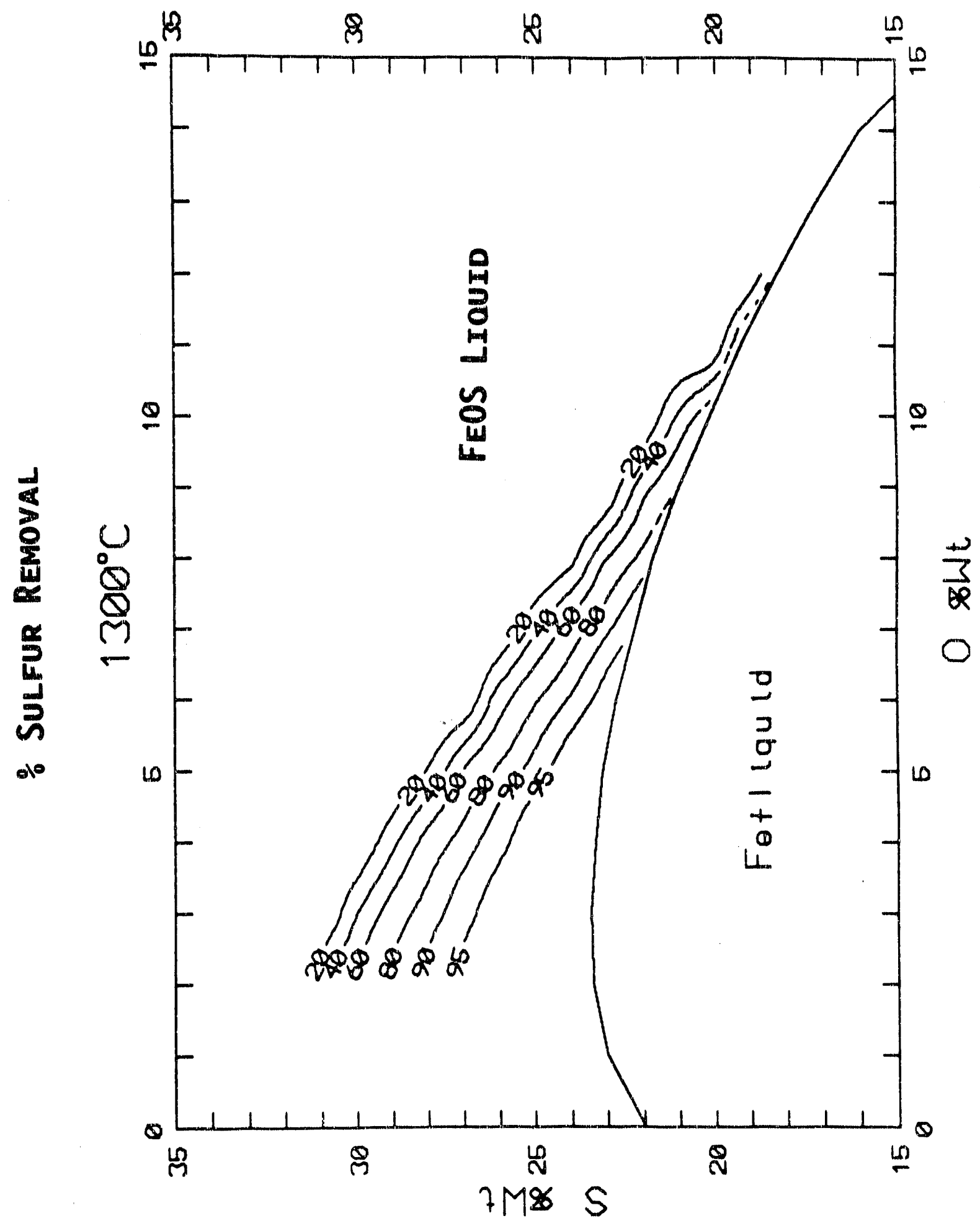

Figure 20

Isothermal Section Fe-O.S System $\left(1300^{\circ} \mathrm{C}\right)$

\% Sulfur Removal at Equilibrium 


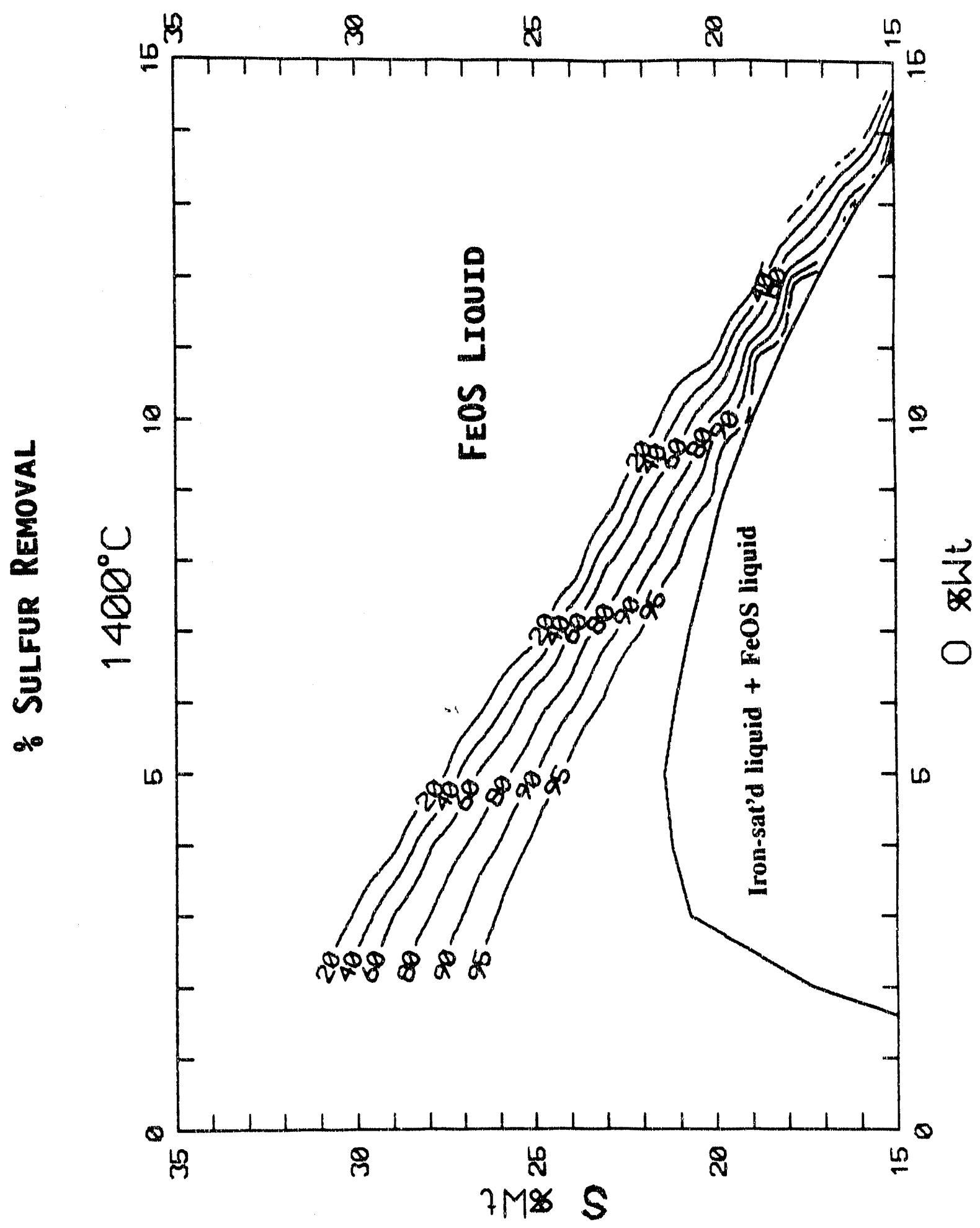

Figure 21 


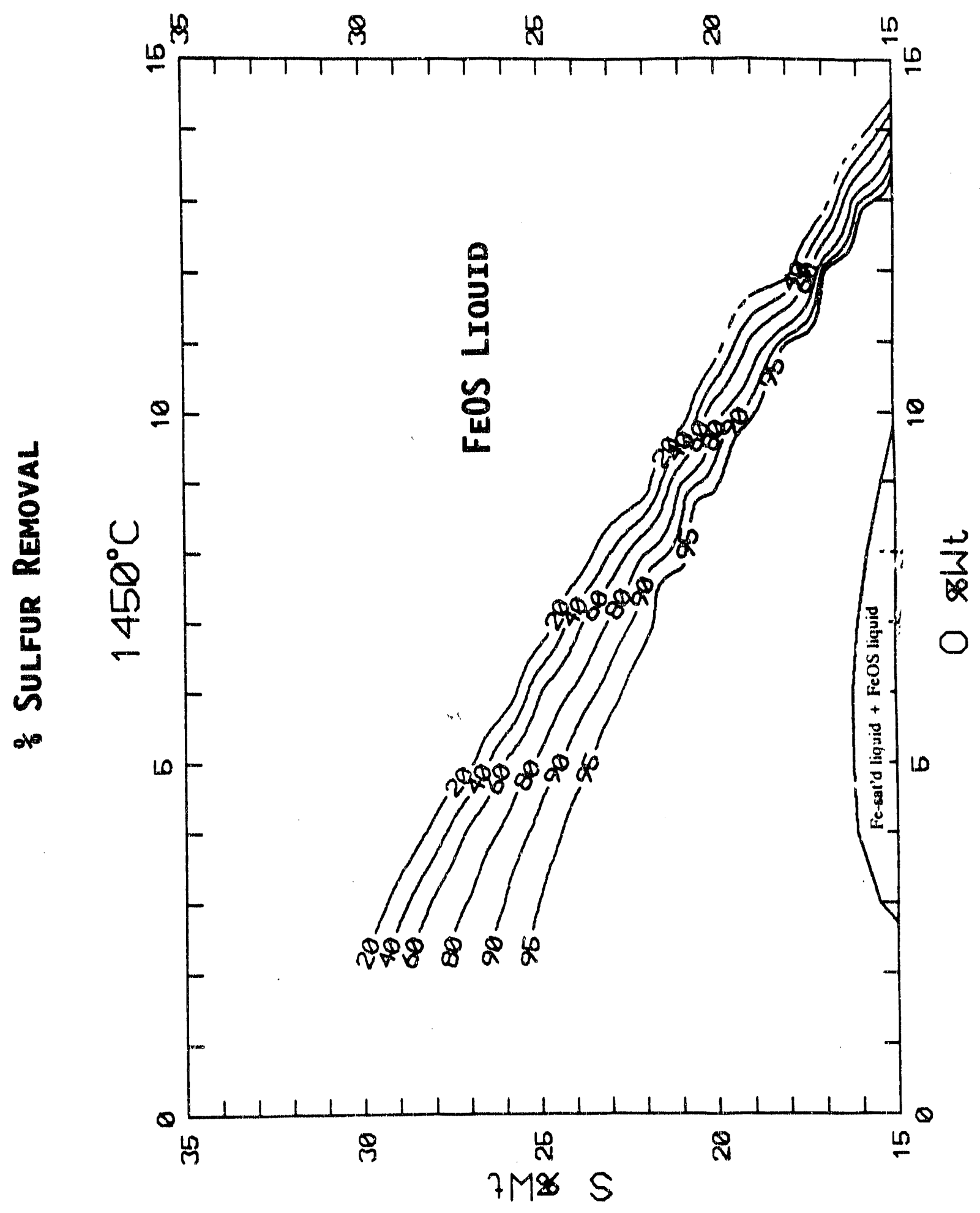

Figure 22

Isothermal Section Fe-O-S System $\left(1450^{\circ} \mathrm{C}\right)$

$\%$ Sulfur Removal at Equilibrium 


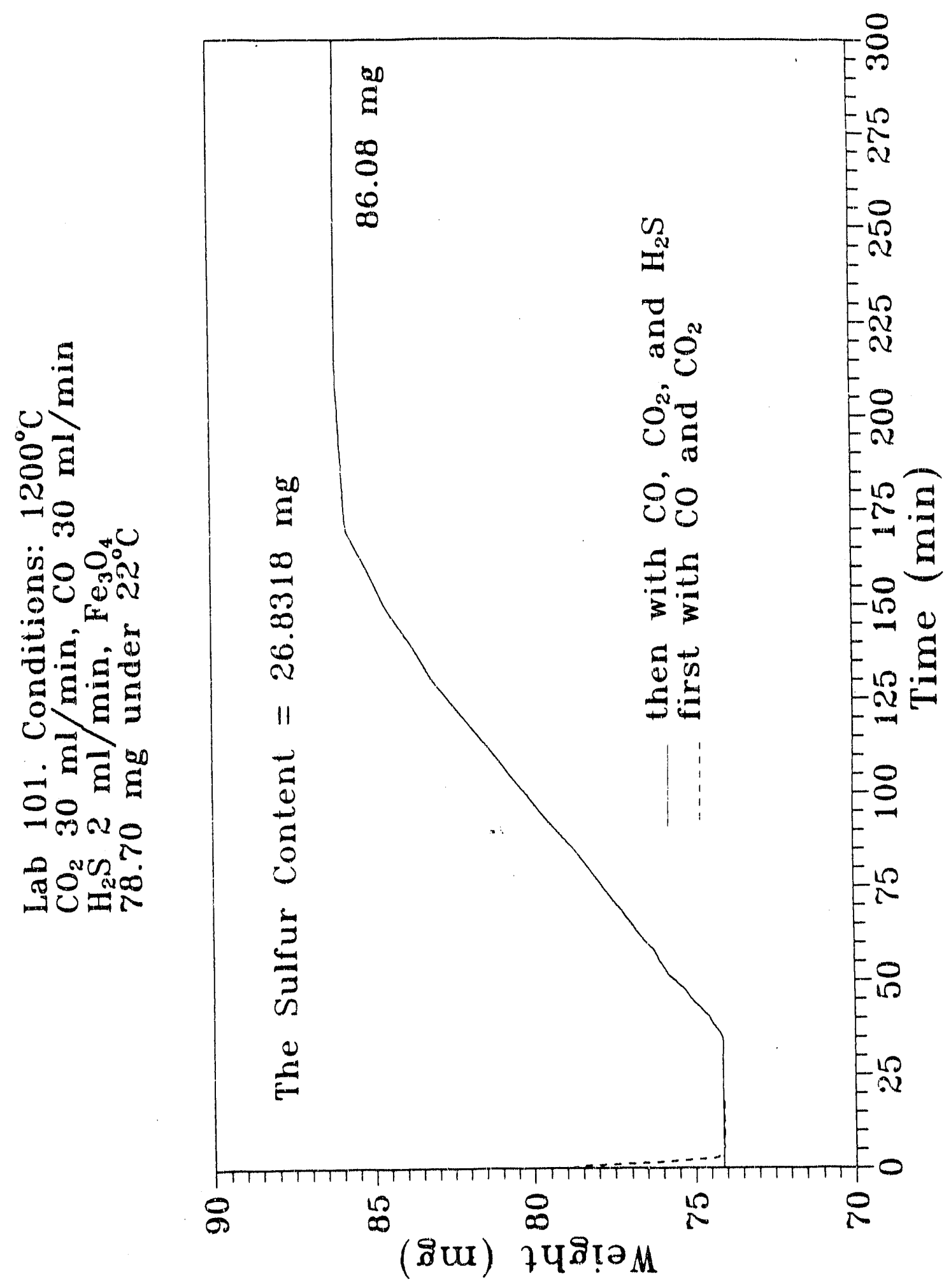

Figure 23

Thermo Gravimetric Analysis on Magnetite Test 101 Dashed line for conditions of no sulfide in gas 


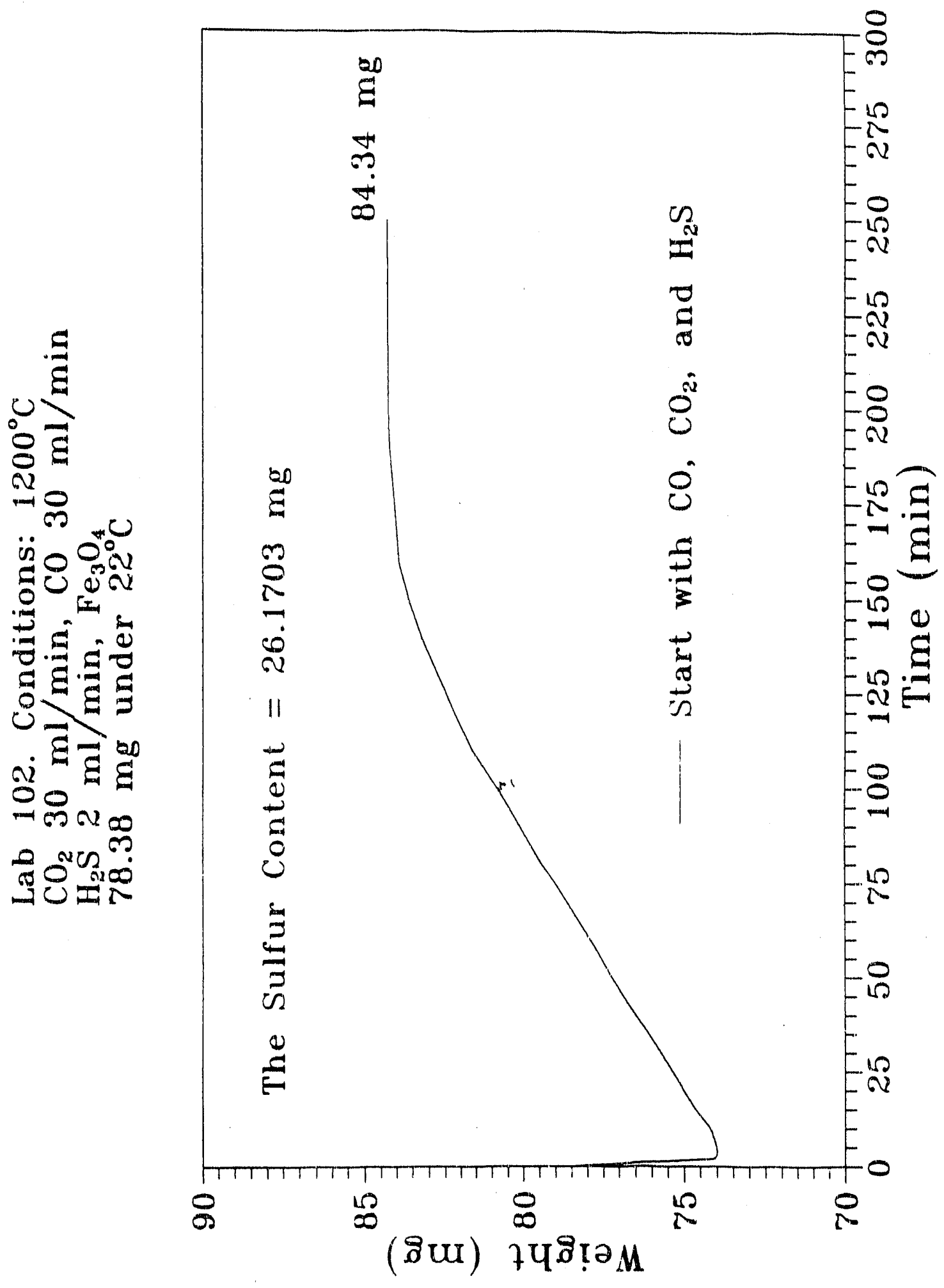

Figure 24

Thermo Gravimetric Analysis on Magnetite Test 102 


\section{APPENDIX A \\ MATHEMATICAL TREATMENT FOR REPRESENTING DATA ON THERMODYNAMICS OF IRON-OXYSULFIDE PHASE IN THE Fe-O-S SYSTEM}

\section{Purpose}

The goals of this model is to develop a mathematical description of the activity coefficients of the iron oxysulfide that will:

(a) reproduce the reported and measured data and

(b) serve to interpolate or extrapolate the system behavior to regions of temperature $\left(1000-1500^{\circ} \mathrm{C}\right)$ or composition that have not been measured.

2. Method

Under conditions of fixed composition and pressure, the partial pressure of sulfur and oxygen as function of temperature can be expressed:

$$
\left(\frac{\partial \ln P_{i}}{\partial T}\right)_{P, n_{i}}=\frac{\Delta H^{0}}{R T^{2}}
$$

where the $\mathrm{P}_{\mathrm{i}}=\mathrm{P}_{\mathrm{S} 2}$ or $\mathrm{P}_{\mathrm{O} 2}$.

Integration gives

$$
\int_{P_{1,1}}^{P_{1}} d \operatorname{din} P_{i}=\int_{T_{1}}^{T} \frac{\Delta H^{0}}{R T^{2}} d T
$$

When the temperature range involved is not appreciable, and in the absence of any phase change in the participating species, one can treat $\Delta \mathrm{H}^{\circ}$ as being independent of temperature and directly integrate above equation to obtain:

$$
\ln \frac{P_{i}}{P_{i, 1}}=-\frac{\Delta H^{\circ}}{R}\left(\frac{1}{T}-\frac{1}{T_{1}}\right)
$$




$$
\begin{aligned}
& 1 n P S_{2}=\ln K_{s}+2 \ln X_{s}+\left(k_{s o}+k_{o s}\right) x_{0}+\left(k_{s F e}+k_{f e s}\right) X_{F e} \\
& \text { - }\left(k_{\mathrm{SO}}+k_{\mathrm{OS}}\right) \mathrm{X}_{\mathrm{s}} \mathrm{X}_{\mathrm{O}}-\left(\mathrm{k}_{\mathrm{SFe}}+\mathrm{k}_{\mathrm{FeS}}\right) \mathrm{X}_{\mathrm{s}} \mathrm{X}_{\mathrm{Fe}}-\left(\mathrm{k}_{\mathrm{OFe}}+\mathrm{k}_{\mathrm{FFO}}\right) X_{0} X_{\mathrm{Fe}}
\end{aligned}
$$

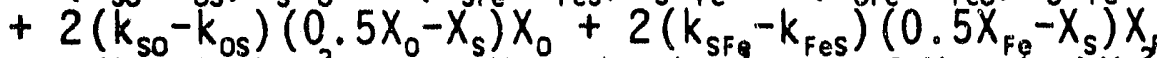

$$
\begin{aligned}
& +2\left(k_{s o}-k_{o s}\right) x_{s}^{2} X_{0}+2\left(k_{s F e}-k_{F e s}\right) x_{s}^{2} x_{F g}+2\left(k_{o s}-k_{s o}\right) X_{0}^{2} X_{s} \\
& +2\left(k_{\mathrm{OFe}}-k_{\mathrm{FeO}}\right) X_{0}^{2} X_{\mathrm{Fe}}+2\left(k_{\mathrm{Fes}}-k_{\mathrm{SFe}}\right) X_{\mathrm{Fe}}{ }^{2} X_{\mathrm{s}}+2\left(\mathrm{k}_{\mathrm{FeO}}-k_{\mathrm{FeO}}\right) X_{\mathrm{Fe}}{ }^{2} X_{\mathrm{O}}
\end{aligned}
$$

There are seven unknown parameters $\left(\ln \mathrm{K}_{\mathrm{S}}, \mathrm{k}_{\mathrm{SO}}, \mathrm{k}_{\mathrm{OS}}, \mathrm{k}_{\mathrm{SFe}}, \mathrm{k}_{\mathrm{FeS}}, \mathrm{k}_{\mathrm{OFe}}, \mathrm{k}_{\mathrm{FeO}}\right)$.

Similarly the equation for partial pressure of oxygen can be expressed as above equation except the character $\mathrm{S}$ is replaced by $\mathrm{O}$.

The next step in model development is to find the value of the parameters in equation 7 that give a best fit to available data in which some are measured and others are calculated from equation 4 at given temperature.

First one defines an objective function.

$$
O B J=\sum_{i=1}^{n}\left[\log \left(P_{i}\right)_{\text {model }}-\log \left(P_{i}\right)_{\text {measure }}\right]^{2}
$$

A nonlinear optimization computer program is developed to use 44 point data to obtain the seven unknown parameters in equation 7 in order to make the objective function minimum.

Tables 1 and 2 are the examples for partial pressure of sulfur and oxygen at $1200^{\circ} \mathrm{C}$. 


\section{Table 1}

The measured and modeling data and the parameters for partial pressure of sulfur at $1200{ }^{\circ} \mathrm{C}$.

$$
\begin{array}{r}
\text { The Composition wt\% } \\
0
\end{array}
$$

$\begin{array}{rrr}0 & 28.5 & 71.5 \\ 1 & 28.25 & 70.75 \\ 2 & 27.7 & 70.3 \\ 3 & 27 & 70 \\ 4 & 26.15 & 69.85 \\ 5 & 25.3 & 69.7 \\ 6 & 24.45 & 69.55 \\ 7 & 23.5 & 69.5 \\ 8 & 22.5 & 69.5 \\ 9 & 21.5 & 69.5 \\ 10 & 20.5 & 69.5 \\ 0 & 30.95 & 69.05 \\ 1 & 30.3 & 68.7 \\ 2 & 29.5 & 68.5 \\ 3 & 28.6 & 68.4 \\ 4 & 27.6 & 68.4 \\ 5 & 26.4 & 68.6 \\ 6 & 25.3 & 68.7 \\ 7 & 24.1 & 68.9 \\ 8 & 22.95 & 69.05 \\ 9 & 21.8 & 69.2 \\ 10 & 20.75 & 69.25 \\ 0 & 33.75 & 66.25 \\ 1 & 32.95 & 66.05 \\ 2 & 31.9 & 66.1 \\ 3 & 30.75 & 66.25 \\ 4 & 29.6 & 66.4 \\ 5 & 28.25 & 66.75 \\ 6 & 26.85 & 67.15 \\ 7 & 25.1 & 67.9 \\ 8 & 23.8 & 68.2 \\ 9 & 22.3 & 68.7 \\ 10 & 21 & 69 \\ 0 & 35 & 65 \\ 1 & 34.3 & 64.7 \\ 2 & 33.4 & 64.6 \\ & & \end{array}$

$\log \left(\right.$ PS2) at $1200^{\circ} \mathrm{C}$

Modeled Measured 
Table 1

The measured and modeling data and the parameters for partial pressure of sulfur at $1200{ }^{\circ} \mathrm{C}$.

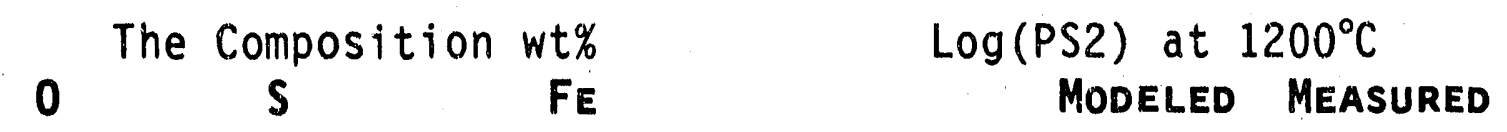

$\begin{array}{rrrrr}0 & 28.5 & 71.5 & -5.55 & -5.5 \\ 1 & 28.25 & 70.75 & -5.84 & -5.5 \\ 2 & 27.7 & 70.3 & -5.97 & -5.5 \\ 3 & 27 & 70 & -5.95 & -5.5 \\ 4 & 26.15 & 69.85 & -5.87 & -5.5 \\ 5 & 25.3 & 69.7 & -5.69 & -5.5 \\ 6 & 24.45 & 69.55 & -5.44 & -5.5 \\ 7 & 23.5 & 69.5 & -5.27 & -5.5 \\ 8 & 22.5 & 69.5 & -5.17 & -5.5 \\ 9 & 21.5 & 69.5 & -5.14 & -5.5 \\ 10 & 20.5 & 69.5 & -5.19 & -5.5 \\ 0 & 30.95 & 69.05 & -4.43 & -5 \\ 1 & 30.3 & 68.7 & -4.83 & -5 \\ 2 & 29.5 & 68.5 & -5.00 & -5 \\ 3 & 28.6 & 68.4 & -5.00 & -5 \\ 4 & 27.6 & 68.4 & -4.91 & -5 \\ 5 & 26.4 & 68.6 & -4.87 & -5 \\ 6 & 25.3 & 68.7 & -4.74 & -5 \\ 7 & 24.1 & 68.9 & -4.72 & -5 \\ 8 & 22.95 & 69.05 & -4.72 & -5 \\ 9 & 21.8 & 69.2 & -4.80 & -5 \\ 10 & 20.75 & 69.25 & -4.88 & -5 \\ 0 & 33.75 & 66.25 & -3.45 & -4 \\ 1 & 32.95 & 66.05 & -3.80 & -4 \\ 2 & 31.9 & 66.1 & -3.94 & -4 \\ 3 & 30.75 & 66.25 & -3.92 & -4 \\ 4 & 29.6 & 66.4 & -3.77 & -4 \\ 5 & 28.25 & 66.75 & -3.66 & -4 \\ 6 & 26.85 & 67.15 & -3.58 & -4 \\ 7 & 25.1 & 67.9 & -3.86 & -4 \\ 8 & 23.8 & 68.2 & -3.90 & -4 \\ 9 & 22.3 & 68.7 & -4.26 & -4 \\ 10 & 21 & 69 & -4.59 & -4 \\ 0 & 35 & 65 & -3.11 & -3 \\ 1 & 34.3 & 64.7 & -3.39 & -3 \\ 2 & 33.4 & 64.6 & -3.42 & -3\end{array}$




$\begin{array}{rrrrr}3 & 32.2 & 64.8 & -3.32 & -3 \\ 4 & 30.95 & 65.05 & -3.11 & -3 \\ 5 & 29.4 & 65.6 & -2.99 & -3 \\ 6 & 27.9 & 66.1 & -2.88 & -3 \\ 7 & 26.2 & 66.8 & -2.98 & -3 \\ 8 & 24.6 & 67.4 & -3.17 & -3 \\ 9 & 23 & 68 & -3.53 & -3 \\ 10 & 21.6 & 68.4 & -3.89 & -3 \\ & & & \\ k_{\text {SO }}=-3.722 \times 10^{-2} & k_{\text {OS }}=-3.685 \times 10^{-2} & \\ k_{\text {SFe }}=-1.708 \times 10^{-2} & k_{\text {Fes }}=-1.712 \times 10^{-2} & \\ k_{\text {OFe }}=-2.072 \times 10^{-2} & k_{\text {Feo }}=-2.080 \times 10^{-2} & \end{array}$

TABLE 2

The measured and modeling data and parameters for partial pressure of oxygen at $1200{ }^{\circ} \mathrm{C}$

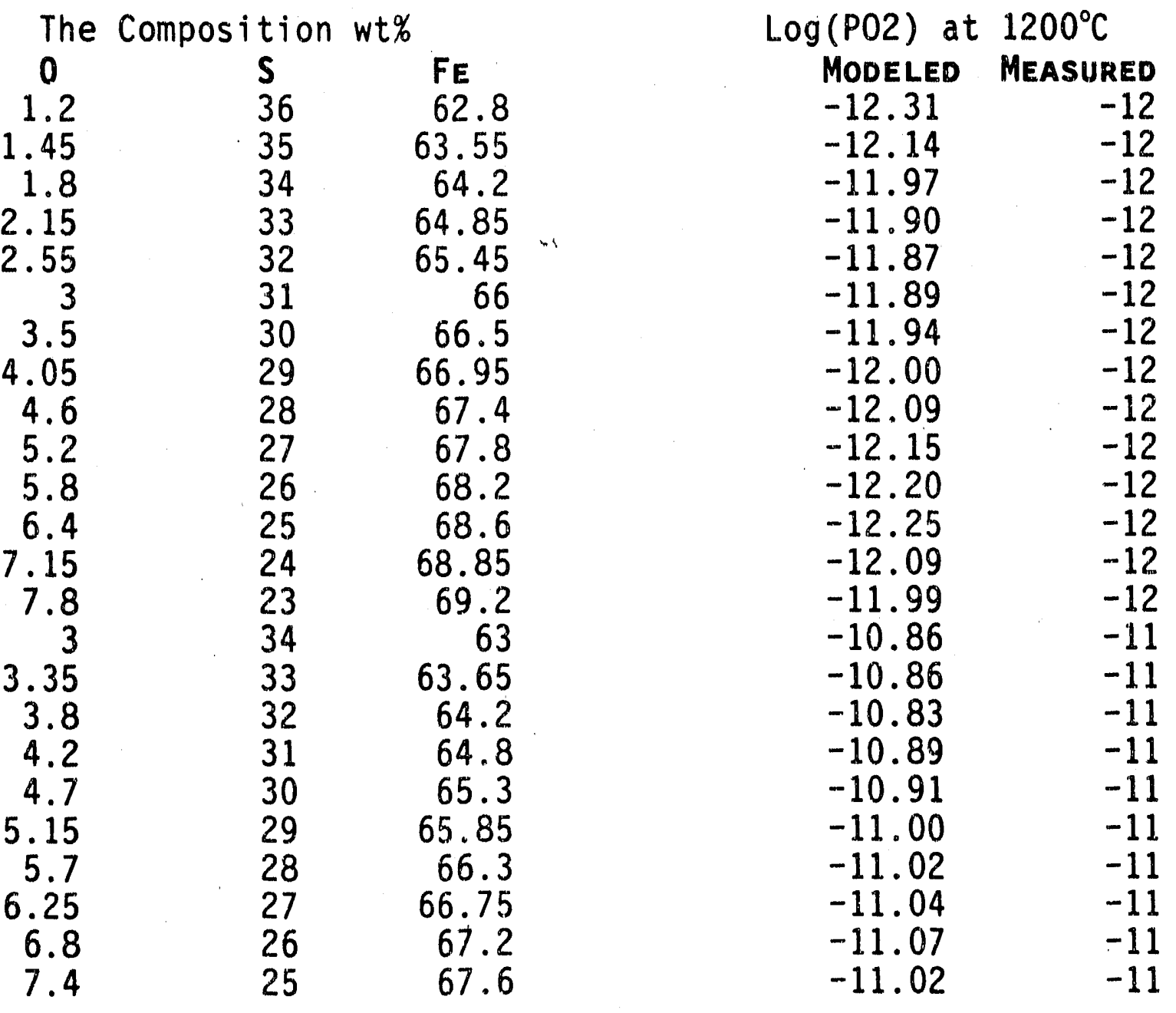




\begin{tabular}{|c|c|c|}
\hline $\begin{array}{r}8.1 \\
8.75 \\
5.15 \\
5.6 \\
6.05 \\
6.55 \\
7.05 \\
7.6 \\
8.1 \\
8.75 \\
7.25 \\
7.8 \\
8.3 \\
8.8 \\
9.4 \\
7.9 \\
8.4 \\
8.9 \\
9.4 \\
10\end{array}$ & $\begin{array}{c}24 \\
23 \\
31 \\
30 \\
29 \\
28 \\
27 \\
26 \\
25 \\
24 \\
28 \\
27 \\
26 \\
25 \\
24 \\
28 \\
27 \\
26 \\
25 \\
24 \\
k_{\text {os }}=-5.888 \times 10^{-3} \\
k_{\text {ofe }}=-9.705 \times 10^{-3} \\
k_{\text {sfe }}=-1.256 \times 10^{-2} \\
l_{\text {InK }}=-30.715\end{array}$ & $\begin{array}{r}67.9 \\
68.25 \\
63.85 \\
64.4 \\
64.95 \\
65.45 \\
65.95 \\
66.4 \\
66.9 \\
67.25 \\
64.75 \\
65.2 \\
65.7 \\
66.2 \\
66.6 \\
64.1 \\
64.6 \\
65.1 \\
65.6 \\
66\end{array}$ \\
\hline
\end{tabular}

$-10.80$

$-11$

$-10.60$

$-11$

$-9.89$

$-10$

$-9.93$

$-10$

$-10.00$

$-10$

$-10.02$

$-10$

$-10.06$

$-10.02$

$-10$

$-10.05$

$-9.83$

$-10$

$-9.12$

$-9.04$

$-10$

$-9.03$

$-10$

$-9$

$-9.01$

$-8.82$

$-8.22$

$-9$

$-8.18$

$-8.14$

$-8.09$

$-9$

$-9$

$-8$

$-7.85$

$-8$

$-8$

$-8$

$k_{\text {sO }}=-5.638 \times 10^{-3}$
$k_{\text {feO }}=-1.023 \times 10^{-2}$
$k_{\mathrm{feS}}=-1.254 \times 10^{-2}$ 

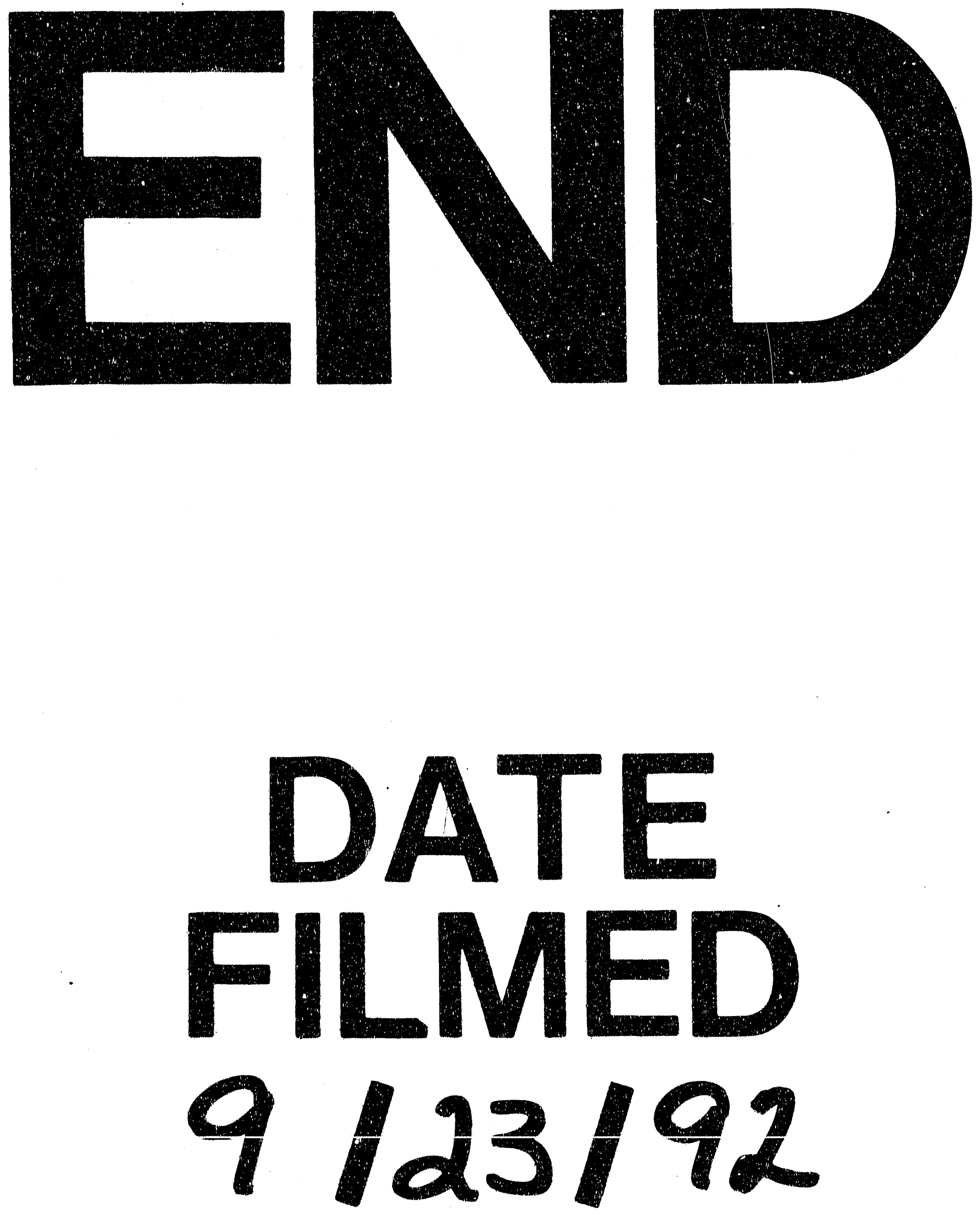
